Article

\title{
Achieving Sustainability in Food Systems: Addressing Changing Climate through Real Time Nitrogen and Weed Management in a Conservation Agriculture-Based Maize-Wheat System
}

\author{
Kapila Shekhawat, Vinod K. Singh *, Sanjay Singh Rathore*(D), Rishi Raj and T. K. Das
}

Citation: Shekhawat, K.; Singh, V.K.; Rathore, S.S.; Raj, R.; Das, T.K. Achieving Sustainability in Food Systems: Addressing Changing Climate through Real Time Nitrogen and Weed Management in a Conservation Agriculture-Based Maize-Wheat System. Sustainability 2021, 13, 5010. https://doi.org/ $10.3390 /$ su13095010

Academic Editors: Tek Sapkota, Tai McClellan Maaz and Prajal Pradhan

Received: 1 April 2021

Accepted: 28 April 2021

Published: 29 April 2021

Publisher's Note: MDPI stays neutral with regard to jurisdictional claims in published maps and institutional affiliations.

Copyright: (c) 2021 by the authors. Licensee MDPI, Basel, Switzerland. This article is an open access article distributed under the terms and conditions of the Creative Commons Attribution (CC BY) license (https:// creativecommons.org/licenses/by/ $4.0 /)$.
Division of Agronomy, ICAR-Indian Agricultural Research Institute (IARI), New Delhi 110 012, India; drrathorekapila@gmail.com (K.S.); rishirajiari@gmail.com (R.R.); tkdas64@gmail.com (T.K.D.)

* Correspondence: vkumarsingh_01@yahoo.com (V.K.S.); sanjayrathorears@gmail.com (S.S.R.)

Abstract: The proven significance of conservation agriculture (CA) in enhancing agronomic productivity and resource use efficiency across diverse agro-ecologies is often challenged by weed interference and nitrogen $(\mathrm{N})$ immobilization. The collective effect of real-time $\mathrm{N}$ and weed management has been scarcely studied. To evaluate the appropriateness of sensor-based $\mathrm{N}$ management in conjunction with a broad-spectrum weed control strategy for the maize-wheat system, an experiment was conducted at ICAR - Indian Agricultural Research Institute-in New Delhi, India, during 2015-2016 and 2016-2017. Weed management in maize through Sesbania brown manure followed by post-emergence application of 2,4-D $(\mathrm{BM}+2,4-\mathrm{D})$ in maize and tank-mix clodinafop-propargyl $\left(60 \mathrm{~g} \mathrm{ha}^{-1}\right)$ and carfentrazone $\left(20 \mathrm{~g} \mathrm{ha}^{-1}\right)$ (Clodi+carfentra) in wheat resulted in minimum weed infestation in both crops. It also resulted in highest maize (5.92 and $6.08 \mathrm{t} \mathrm{ha}^{-1}$ ) and wheat grain yields (4.91 and $5.4 \mathrm{t} \mathrm{ha}^{-1}$ ) during 2015-2016 and 2016-2017, respectively. Half of the $\mathrm{N}$ requirement, when applied as basal and the rest as guided by Optical crop sensor, resulted in saving 56 and $59 \mathrm{~kg} \mathrm{~N} \mathrm{ha}^{-1}$ in the maize-wheat system, respectively, over $100 \% \mathrm{~N}$ application as farmers' fertilizer practice during the two consecutive years. Interactive effect of $\mathrm{N}$ and weed management on economic yield of maize and wheat was also significant and maximum yield was obtained with $50 \% \mathrm{~N}$ application as basal + rest as per Optical crop sensor and weed management through BM+2,4-D in maize and Clodi+carfentra in wheat crop. The study concludes that real-time $\mathrm{N}$ management, complemented with appropriate weed management, improved growth, enhanced agronomic productivity and endorsed N saving under a CA-based maize-wheat system in Trans Indo-Gangetic Plains.

Keywords: brown manure; optical crop sensor; real-time nitrogen management; weed menace; weed shift

\section{Introduction}

Maize (Zea mays L.)-wheat (Triticum aestivum L.) system has been established as a potential alternative cropping system after rice (Oryza sativa L.)-wheat system in the IndoGangetic Plains of Indian sub-continent due to emerging challenges of unsustainability. Globally, maize and wheat are the preferred food for 0.9 and 2.5 billion people which are grown over 197 and 218 million hectares area, respectively. Together these crops add about 1.9 billion tonnes food grain [1]. The quality protein, viz. lysine and tryptophan in maize may help reduce malnutrition, especially in the developing nations. Maize-wheat system occupies a 1.83-million-hectare area, contributes about 3\% to the national food production and is the third most important system after rice-wheat and rice-rice systems in India [2]. Diversifying rice-wheat system with maize-wheat system under conservation agriculture (CA) addresses the existing defies of yield stagnation, declining soil organic carbon status and environmental trade-offs under increasing climate vagaries and erratic rainfall patterns with climate change. However, the gratuitous weed interference and 
nitrogen $(\mathrm{N})$ immobilization in the early crop establishment phase under CA have glitched its adoption across various cropping systems [3,4]. Weeds have been reported to cause up to $70 \%$ yield loss in maize and $10 \%-25 \%$ in wheat $[5,6]$. The over-reliance on chemical weed management in zero till (ZT)-production systems subverts many benefits of adopting CA. Growing Sesbania aculeata as brown manure is the zero-till version of green manure, which is used to suppress initial weed establishment and its growth; supply organic matter and $\mathrm{N}$ in soil and improve soil structure [7-9]. The smothering effect offered by Sesbania as a brown manure crop up to initial 25 days after sowing (DAS) reduces weed density by $50 \%$ in maize [10]. Besides, it maintains a residue cover on soil till 45 DAS after termination and the critical period of crop competition gets over by then [11,12].

Crop-weed interactions are strongly influenced by the rate and timing of application of various plant nutrients, especially $\mathrm{N}[13,14]$. $\mathrm{N}$ fertilization may increase plant biomass or weed biomass or both, since weeds and crops co-exist in the field [15]. The weed competes more severely with crops for $\mathrm{N}$ during initial growth and any management approach which provides $\mathrm{N}$ as per crop demand, instead of blanket $\mathrm{N}$ application will certainly improve the competitive ability of the crop against weeds [16]. The diversity and dominance of weed flora may also alter in response to modification in N supply, crop residue return, herbicides used and their application pattern under CA.

To improve the response of production systems and augment agronomic productivity under CA, alterations in the management options for weed and $\mathrm{N}$ become necessary. Hence, an adaptive management strategy using herbicide combinations and mixtures, sensor-based real time $\mathrm{N}$ management and organic nutrient source employment through maize-Sesbania co-culture as a collective approach for weed and $\mathrm{N}$ management needs to be standardized. Once optimized, these functionally convergent agronomic management strategies will enhance system productivity and resilience against the threats imposed under the changing climate scenario [8].

However, specific information considering weed distribution, their composition and dynamics with the use of herbicide mixtures or Sesbania brown manure vis-à-vis N management options under medium term CA-based production systems is lacking. The present study has been planned to evaluate the differential impact of choosing an amalgamation of weed management approaches with Optical crop sensor guided N application on cropweed interference, $\mathrm{N}$ saving and agronomic productivity under $\mathrm{CA}$. The experiment also tests the hypothesis that the management approach which could suppress weeds up to 70 DAS remains desirable over pre-emergence herbicide, given the choice of avoiding sequential herbicide application. The information generated from the study would be of prime importance in identifying the most suitable weed management approach compatible with sensor-guided $\mathrm{N}$ application in a CA-based maize-wheat system.

\section{Materials and Methods}

\subsection{Experimental Site}

This field study was conducted during the rainy (monsoon) and winter seasons of 2015-2016 and 2016-2017 at Indian Agricultural Research Institute (IARI) $\left(28^{\circ} 40^{\prime} \mathrm{N}\right.$, $77^{\circ} 11^{\prime} \mathrm{E} ; 228 \mathrm{~m}$ amsl) in New Delhi, India. The climate of the experimental site is a combination of monsoon-influenced humid subtropical and semi-arid with high variation between summer and winter temperatures and precipitation. The weather variables, including rainfall, maximum and minimum temperatures during the maize and wheat growing periods of 2015-2016 and 2016-2017 were recorded at the IARI Meteorological Observatory, New Delhi, and is given in Figure 1. The soil texture was sandy loam, Typic Haplustept (sand: $63.7 \%$; silt: $17.1 \%$ and clay: $19.2 \%$ ) and the initial $\mathrm{KMnO}_{4}$ oxidizable $\mathrm{N}$, Olsen's available $\mathrm{P}_{2} \mathrm{O}_{5}$ and $1 \mathrm{~N}$ NH4O AC-extractable $\mathrm{K}$ were $171 \mathrm{~kg} \mathrm{ha}^{-1}, 10.5 \mathrm{~kg} \mathrm{ha}^{-1}$ and $237 \mathrm{~kg} \mathrm{ha}^{-1}$, respectively, at $0-0.15 \mathrm{~m}$ depth. The soil exhibits the $\mathrm{pH}$ (1:2.5 soil:water), EC, organic carbon and bulk density as 7.9, $2.91 \mathrm{~d} \mathrm{Sm}^{-1}, 0.25 \mathrm{~g} \mathrm{~kg}^{-1}$ and $1.56 \mathrm{Mg} \mathrm{m}^{-3}$. Since 2009, the field is under CA-based soybean-wheat and maize-wheat for four and two years, respectively, with $50 \%$ residue of the previous crop retained in the succeeding crop. 

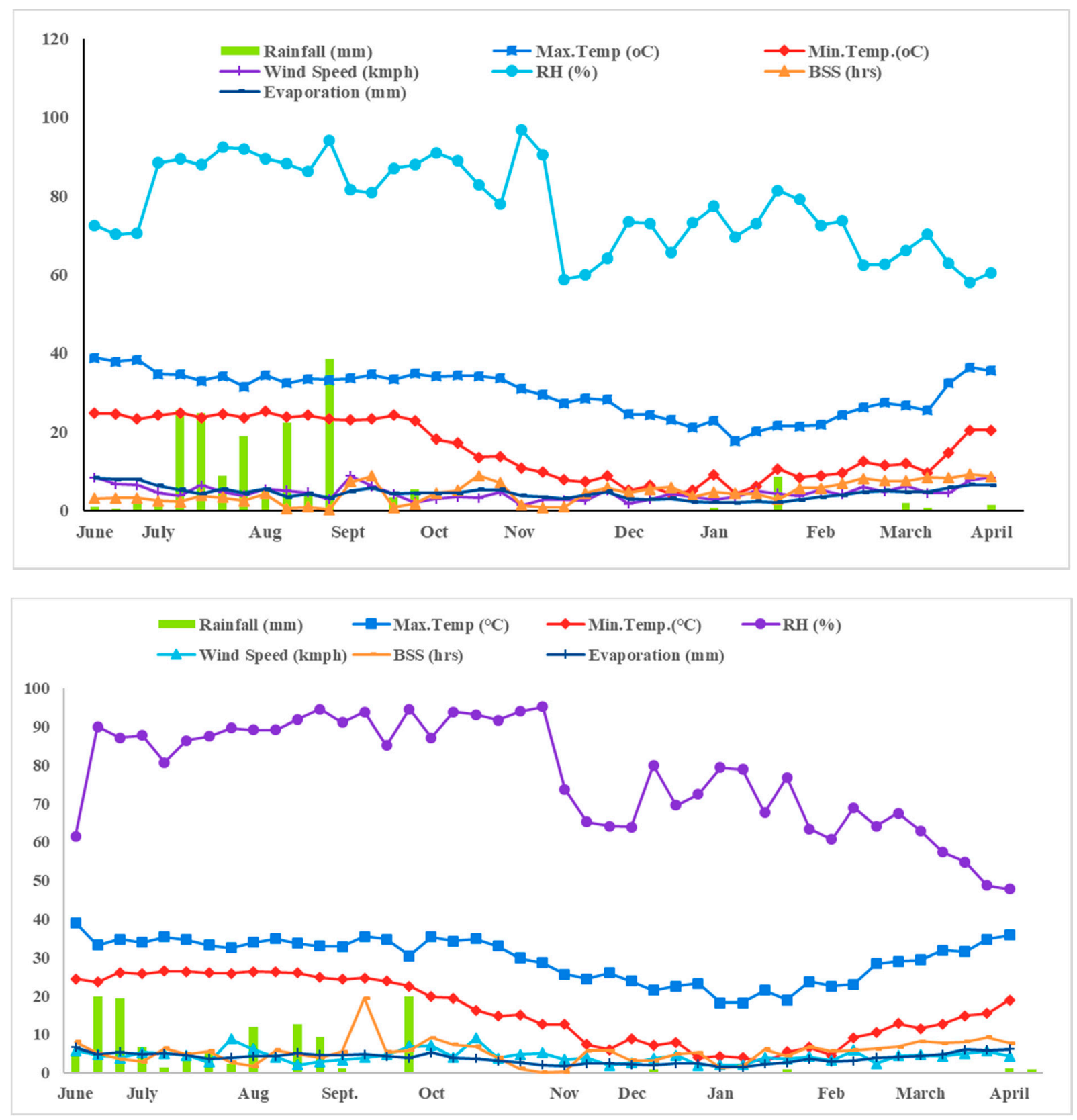

Figure 1. Weather data for standard weeks during the experimental period (2015-2016 and 2016-2017).

\subsection{Experiment Details}

The experiment was conducted in a split-plot design with weed management options in the main-plot, nitrogen management treatments in the sub-plot and replicated thrice. The net plot area was $29.4 \mathrm{~m}^{-2}(7 \mathrm{~m} \times 4.2 \mathrm{~m})$. The treatment details are given in Table 1 .

\subsection{Crop Management}

The experiment was conducted for two consecutive years (2015-2016 and 2016-2017). Maize cultivar PMH-1 (released for irrigated conditions in the rainy season of IndoGangetic Plains, matures in 95 days with average productivity of $5.25 \mathrm{t} \mathrm{ha}^{-1}$ ) and wheat cultivar HD-2967 (released for the north-western Plain Zone of India matures in 142 days with average productivity of $5.0 \mathrm{t} \mathrm{ha}^{-1}$ ). The sowing of maize was done on 7 th and 5 th July and of wheat was done on 25th and 28th October during 2015 and 2016, respectively, with a Happy-Seeder machine under untilled soil. Sesbania aculeata L. as brown manure 
was co-cultured (seed rate of $20 \mathrm{~kg} \mathrm{ha}^{-1}$ ) with maize. The soil moisture was maintained during both crop growing seasons through check basin irrigation (6 $\mathrm{mm}$ depth) at the critical stages of crop growth.

Table 1. Treatments details in maize (rainy season) and wheat (winter season).

\begin{tabular}{|c|c|c|c|c|}
\hline \multirow{2}{*}{$\begin{array}{l}\text { Main Plot/Weed } \\
\text { Management }\end{array}$} & \multirow{2}{*}{$\begin{array}{l}\text { Maize (Rainy } \\
\text { Season) }\end{array}$} & \multirow{2}{*}{$\begin{array}{l}\text { Wheat (Winter } \\
\text { Season) }\end{array}$} & \multicolumn{2}{|c|}{ Treatment Short Forms } \\
\hline & & & Maize & Wheat \\
\hline W1 & Unweeded check & Weedy check & UWC & UWC \\
\hline W2 & $\begin{array}{c}\text { Herbicide mixture } \\
\text { as atrazine } \\
\left(0.75 \mathrm{~kg} \text { a.i. ha }{ }^{-1}\right)+ \\
\text { pendimethalin } \\
\left(0.75 \mathrm{~kg} \text { a.i. } \mathrm{ha}^{-1}\right) \text { as } \\
\text { tank mix }\end{array}$ & $\begin{array}{l}\text { Herbicide mixture of } \\
\text { pendimethalin } \\
\left(1 \mathrm{~kg} \text { a.i. } \mathrm{ha}^{-1}\right)+ \\
\text { carfentrazone } \\
(20 \mathrm{~g} / \mathrm{ha}) \text { as tank mix }\end{array}$ & $\begin{array}{c}\text { Atra }+ \\
\text { pendi }(P R E)\end{array}$ & $\begin{array}{l}\text { Pendi + } \\
\text { carfentra } \\
(\text { PRE })\end{array}$ \\
\hline W3 & $\begin{array}{l}\text { Brown manure } \\
\text { (terminated at } 25 \\
\text { DAS by } 2,4-\mathrm{D})\end{array}$ & $\begin{array}{l}\text { Clodinafop- } \\
\text { propargyl }(60 \mathrm{~g} \text { a.i. } \\
\text { ha) + carfentrazone } \\
\left(20 \mathrm{~g} \text { a.i. ha }{ }^{-1}\right) \text { as } \\
\text { tank mix at } 25 \text { DAS }\end{array}$ & $\begin{array}{l}\mathrm{BM}+2,4-\mathrm{D} \\
(\mathrm{POST})\end{array}$ & $\begin{array}{l}\text { Clodi }+ \\
\text { carfentra } \\
(\mathrm{POST})\end{array}$ \\
\hline \multicolumn{5}{|c|}{ Sub-plot/N management (maize and wheat) } \\
\hline N1 & \multicolumn{2}{|c|}{$\begin{array}{c}50 \% \text { basal }+2 \text { splits at } 30 \text { DAS and } 50 \text { DAS } \\
(25 \%+25 \%) \text { in maize and wheat }\end{array}$} & \multicolumn{2}{|c|}{$\begin{array}{l}\text { FFP: Basal } 50 \%+2 \text { splits } \\
\qquad(25 \%+25 \%)\end{array}$} \\
\hline N2 & \multicolumn{2}{|c|}{$100 \%$ Basal } & \multicolumn{2}{|c|}{$100 \%$ Basal } \\
\hline N3 & \multicolumn{2}{|c|}{$\begin{array}{l}75 \% \text { Basal + rest as guided by optical crop } \\
\text { sensor }\end{array}$} & \multicolumn{2}{|c|}{$\begin{array}{l}\text { Basal } 75 \%+\text { rest as } \\
\text { sensor-guided }\end{array}$} \\
\hline N4 & \multicolumn{2}{|c|}{$\begin{array}{c}50 \% \text { Basal }+ \text { rest as guided by optical crop } \\
\text { sensor }\end{array}$} & \multicolumn{2}{|c|}{$\begin{array}{c}\text { Basal } 50 \%+\text { rest as sensor } \\
\text { guided }\end{array}$} \\
\hline
\end{tabular}

\subsection{Weed Management}

In maize, besides UWC (unweeded check), a herbicide mixture of atrazine (6-chloroN2-ethyl-N4-(propan-2-yl)-1,3,5-triazine-2,4-diamine)+pendimethalin (3,4-dimethyl-2,6dinitro-N-pentan-3-yl-aniline) as pre-emergence (PRE) and 2,4-D (2,4-dichlorophenoxy acetic acid) at $0.25 \mathrm{~kg} \mathrm{ha}^{-1}$ as post-emergence (POST) to terminate Sesbania aculeata as brown manure was used. The terminated Sesbania was allowed for in-situ decaying in the field along with the main crop aiming to add organic matter beside weed suppression. Likewise, in wheat besides UWC, a herbicide mixture of pendimethalin+carfentrazone-ethyl (Ethyl 2-chloro -3-(2-chloro-4-fluoro-5-(4-(difluoromethyl)-4,5-diydro-3-methyl-5-oxo-1H-1,2,4 trizol-1-yl) phenyl) propanoate) as PRE and clodinafop-propargyl (prop-2-ynyl(R)-2-(4-(5chloro-3-fluoro-2-pyridyloxy) phenoxy) propionate) + carfentrazone-ethyl as POST was used. The herbicide mixtures were prepared as tank-mixed, applied as per the treatment through a knapsack sprayer with a flat-fan nozzle and water as carrier at $375 \mathrm{~L} \mathrm{ha}^{-1}$ as PRE and POST at 1 and 35 DAS, respectively.

\subsection{Weed Observation}

The weed population was counted with the help of a quadrate $\left(1 \mathrm{~m}^{2}\right)$ thrown randomly at three places in each plot at 35 and 70 DAS in both maize and wheat. Weeds were cut at ground level, washed with tap water, and then identified, counted and expressed in numbers $\mathrm{m}^{-2}$ of broad and narrow-leaved species. The collected weed samples were first sun-dried and later oven-dried at $65^{\circ} \mathrm{C}$ for $48 \mathrm{~h}$, then weighed and the weed biomass was expressed in $\mathrm{g} \mathrm{m}^{-2}$. 


\subsection{Physiological Observation and Yield}

The two important crop variables, plant dry biomass and leaf area index were measured at peak flowering period in maize and heading in wheat (70 DAS and 85 DAS, respectively). The plant dry biomass was measured by random sampling from $0.25 \mathrm{~m}^{2}$ area in maize and wheat. The plant samples were sun-dried followed by oven-drying at $65^{\circ} \mathrm{C}$ to obtain dry weight expressed in $\mathrm{g} \mathrm{m}^{-2}$. Maize cobs were harvested from the net area of each plot and de-husked manually. Maize grains after shelling, and wheat grains after threshing, were cleaned by separating grains from chaff using a winnowing fan and weighed for their yields. The grain yields of maize and wheat were recorded at $15 \%$ and $12 \%$ moisture content, respectively [17].

\subsection{Nutrient Management and GWP Estimation}

The $\mathrm{N}$ fertilizer for both crops were decided on the basis of the soil test values where the fixed amount was to be applied (Table 1). The in-season $\mathrm{N}$ fertilizer for remaining treatments was applied as per the crop demand using an Optical crop sensor (OCS) as neem coated urea. The sensor readings were collected on a clear day by holding the sensor approximately $0.7-0.9 \mathrm{~m}$ above the canopy and walking at a constant speed in the middle rows of all experimental plots, while keeping the sensor path parallel to the rows and the beam of light perpendicular to the row. The efficiency factor (0.5) for south Asian conditions was used as suggested by Bijay-Singh et al. 2018 [18]. The yield response index and fertilizer $\mathrm{N}$ optimization algorithm [19] were used to estimate the in-season crop $\mathrm{N}$ fertilizer requirement using the normalized difference vegetation index (NDVI). The sensor unit has self-contained radiance in both the red $(656 \mathrm{~nm}$ with about $25 \mathrm{~nm}$ full width half magnitude (FWHM)) and near infrared (NIR) (774 with about $25 \mathrm{~nm}$ FWHM) bands.

$$
\mathrm{NDVI}=\frac{\text { NIRref }- \text { REDref }}{\text { NIRref }+ \text { REDref }}
$$

where NDVI is the fractions of NIR and red radiation reflected back from the sensed area. The NDVI readings are entered into an online sensor-based N-rate calculator along with, location, planting date and the time of observation sensing with the sensor. The sensor-based nitrogen (N)-rate calculator outputs response index (RI) as an estimate of the response to added $\mathrm{N}$ fertilizer. For example, a RI of 1.1 advocates a $10 \%$ increase in produce is probable with added $\mathrm{N}$ fertilizer. The RI is measured by dividing the NDVI of the N-rich strip by the NDVI of the adjoining area. The sensor-based $\mathrm{N}$ rate calculator generates two yield potential values, one if the recommended $\mathrm{N}$ rate is applied (YPO) and another if no additional $\mathrm{N}$ is applied (YPN). The recommended $\mathrm{N}$ fertilizer rate is calculated by estimating the difference in $\mathrm{N}$ uptake from the $\mathrm{N}$-rich strip and the area outside of the $\mathrm{N}$ rich strip and was applied as per the demand of the maize and wheat crops. The algorithm used in the sensor-based $\mathrm{N}$-rate calculator is expressed as:

$$
\mathrm{N} \text { rate }=((\mathrm{YPO} X \mathrm{RI})-\mathrm{YPO}) \mathrm{X} \% \mathrm{~N} \text { X NUE factor }
$$

The full doses of phosphorus ( 95 and $80 \mathrm{~kg} \mathrm{P}_{2} \mathrm{O}_{5} \mathrm{ha}^{-1}$ ) using di-ammonium phosphate, and potassium ( 50 and $\left.37.5 \mathrm{~kg} \mathrm{~K}_{2} \mathrm{O} \mathrm{ha}^{-1}\right)$ ) using murate of potash were applied to maize and wheat, respectively, at the time of sowing along with $\mathrm{N}$ doses as per the treatment.

The global warming potential (GWP) was estimated by transforming the GHGs into $\mathrm{CO}_{2}$-equivalents $\left(\mathrm{CO}_{2}\right.$ eq.) using 34 and $298 \mathrm{GWP}$ for $\mathrm{CH}_{4}$ and $\mathrm{N}_{2} \mathrm{O}$, respectively [20]. The GWP in both maize and wheat was estimated using following empirical equation:

GWP $\left(\mathrm{kg} \mathrm{CO}_{2}\right.$ eq. ha $\left.{ }^{-1}\right)=\left(\mathrm{CO}_{2}\left(\mathrm{~kg} \mathrm{ha}^{-1}\right)+\mathrm{N}_{2} \mathrm{O}\left(\mathrm{kg} \mathrm{ha}^{-1}\right) \times 298+\mathrm{CH}_{4}\left(\mathrm{~kg} \mathrm{ha}^{-1}\right) \times 34\right)$

\subsection{Statistical Analysis}

The standard analysis of variance (ANOVA) test and correlation analysis was performed using SAS 9.3 [21]. The variance over years was estimated homogeneously by 
performing Bartlett's chi square test. Tukey's HSD test was carried out to appraise the significance of treatment means at $p \leq 0.05$ for maize and wheat variables studied.

\section{Results}

\subsection{N Application and Global Warming Potential in Maize and Wheat}

The $\mathrm{N}$ demand for both crops was estimated on the soil test values basis keeping in account the soil inherent $\mathrm{N}$ supplying capacity. In both maize and wheat crops, for $\mathrm{N} 3$ and N4 treatments, respectively, $75 \%$ and $50 \%$ of the $\mathrm{N}$ requirement was applied as basal, followed by split applications as guided by the Optical crop sensor (Table 2). Under maize-wheat system, a saving of $25 \mathrm{~kg}$ and $22 \mathrm{~kg} \mathrm{~N}$ in N3 and 56 and $59 \mathrm{~kg} \mathrm{~N} \mathrm{ha}^{-1}$ in N4 during 2015-2016 and 2016-2017, respectively, was recorded over farmers fertilizer application practice, FFP (N1). The global warming potential in terms of equivalent $\mathrm{CO}_{2}$ emitted from the $\mathrm{N}$ fertilizer used was estimated and the lowest emissions were observed in $50 \%$ basal + rest as sensor guided $\mathrm{N}$ application (Table 2). In maize, the highest GWP was recorded under FFP (1.99 and $1.91 \mathrm{tCO}_{2}$ eq. ha ${ }^{-1}$, respectively, during 2015-2016 and 2016-2017, respectively). The total emissions remained similar with 50\% basal +2 splits $(25 \%+25 \%)$, however $75 \%$ basal application and rest as sensor-guided resulted in low emission compared to FPP. The minimum emissions were recorded under $50 \%$ basal $\mathrm{N}$ application and rest as sensor-guided in both maize and wheat during both the years.

Table 2. Optical crop sensor-based nitrogen fertilizer dose prescription $\left(\mathrm{kg} \mathrm{ha}^{-1}\right)$, its scheduling, saving $\left(\mathrm{kg} \mathrm{ha}^{-1}\right)$ and global warming potential ( $\mathrm{CO}_{2}$ eq. ha) in a maize-wheat system.

\begin{tabular}{|c|c|c|c|c|c|c|c|c|c|c|}
\hline \multirow{3}{*}{ Treatment } & \multicolumn{4}{|c|}{ N Application, $\mathrm{kg} \mathrm{ha}^{-1}$} & \multicolumn{2}{|c|}{$\begin{array}{l}\text { N Saving over } \\
\text { FFP in } \\
\text { Maize-Wheat } \\
\text { System }\end{array}$} & \multicolumn{4}{|c|}{$\begin{array}{l}\text { Global Warming Potential } \\
\qquad\left(t \mathrm{CO}_{2} \text { eq. } \mathrm{ha}^{-1}\right)\end{array}$} \\
\hline & \multicolumn{2}{|c|}{ Maize } & \multicolumn{2}{|c|}{ Wheat } & \multirow[b]{2}{*}{$\begin{array}{l}2015- \\
2016\end{array}$} & \multirow[b]{2}{*}{$\begin{array}{l}2016- \\
2017\end{array}$} & \multicolumn{2}{|c|}{ Maize } & \multicolumn{2}{|c|}{ Wheat } \\
\hline & 2015-2016 & 2016-2017 & 2015-2016 & 2016-2017 & & & $\begin{array}{l}2015- \\
2016\end{array}$ & $\begin{array}{l}2016- \\
2017\end{array}$ & $\begin{array}{l}2015- \\
2016\end{array}$ & $\begin{array}{l}2016- \\
2017\end{array}$ \\
\hline FFP & $\begin{array}{c}90+ \\
(45+45) *\end{array}$ & $\begin{array}{c}85+ \\
(42.5+42.5) *\end{array}$ & $\begin{array}{c}75+ \\
(37.5+37.5)\end{array}$ & $\begin{array}{c}76+ \\
(38+38)\end{array}$ & - & - & 1.99 & 1.91 & 1.68 & 1.65 \\
\hline $100 \%$ basal & 178 & 170 & 150 & 148 & - & - & 1.99 & 1.91 & 1.68 & 1.65 \\
\hline $\begin{array}{l}75 \% \text { Basal + rest } \\
\text { as sensor-guided }\end{array}$ & $\begin{array}{c}134+ \\
(15+7)\end{array}$ & $\begin{array}{c}128+ \\
(17+10)\end{array}$ & $\begin{array}{c}113+ \\
(20+14)\end{array}$ & $\begin{array}{c}111+ \\
(20+10)\end{array}$ & 25 & 22 & 1.75 & 1.73 & 1.65 & 1.58 \\
\hline $\begin{array}{l}50 \% \text { Basal + rest } \\
\text { as sensor guided }\end{array}$ & $\begin{array}{c}90+ \\
(25+18+10)\end{array}$ & $\begin{array}{c}85+ \\
(20+13+8)\end{array}$ & $\begin{array}{c}75+ \\
(35+20+10)\end{array}$ & $\begin{array}{c}76+ \\
(30+18+7)\end{array}$ & 56 & 59 & 1.60 & 1.41 & 1.57 & 1.47 \\
\hline
\end{tabular}

* 2 splits were applied at 30 and 50 DAS in maize and wheat; FFP: farmers fertilizers practice.

The lower $\mathrm{N}$ use in N3 and N4 resulted in $12.4 \%$ and $19.7 \%$ reduction in global warming potential in maize and $2.1 \%$ and $6.6 \%$ in wheat over N1 during 2015-2016, respectively. However, this reduction during 2016-2017 was $9.4 \%$ and $26.3 \%$ for maize and $4.7 \%$ and $11.5 \%$ in wheat under N3 and N4, respectively, over N1.

\subsection{Weed Interference in Maize}

The predominant broad-leaved weeds (BLW) encountered during the rainy season were Commelina benghalensis L., Digera arvensis L., Trianthema monogyna L. and Tribulus terrestris L., whereas Cyperus rotundus L., Cynodon dactylon (L.) Pers., Setaria viridis (L.) P.Beauv and Dactyloctenium aegyptium L. Wild. were the predominant narrow leaved weeds (NLW). The density of remaining weeds was considered as others due to their sporadic appearance in various treatments. A higher weed density of NLW was recorded over BLW at 35 and 70 DAS in both crops during both years (Table 3). A 36.5\% and $67.3 \%$ reduction in the BLW density and was recorded through maize-Sesbania co-culture over UWC at 35 and 70 DAS, respectively, during 2015-2016. Moreover, 56.8\% and 43.4\% reduction in total weed dry biomass was recorded at 35 and 70 DAS under maize-Sesbania co-culture over UWC (Table 4). At 70 DAS, a 3.39- and 1.74-fold respective increase in BLW density was recorded 
under UWC and maize-Sesbania co-culture. During 2015-2016, a 26.8\% and 17.8\% reduction in the NLW density was recorded with the application of atrazine + pendimethalin (PRE). During 2016-2017, a 4.23- and 3.33-fold reduction in the BLW density was also recorded with maize-Sesbania co-culture over UWC. This reduction was 3.1- and 3.4-fold in the total weed dry biomass during the second year of experimentation. Among the $\mathrm{N}$ application treatments, the highest weed density at both 35 and 70 DAS was recorded where the entire $\mathrm{N}$ was applied as basal. The weed density under FFP and 75\% as basal and rest as guided by optical crop sensor remained statistically similar at 35 and 70 DAS during both years. The lowest density of both BLW (8.4 and 9.6 per square m) and NLW (15.0 and 22.1 per square $\mathrm{m}$ ) was recorded where $50 \% \mathrm{~N}$ was applied as basal and rest as guided by Optical crop sensor during the second year of experimentation. A higher reduction in the NLW density $(39.9 \%$ and $38.1 \%)$ and in the weed dry biomass $(31.2 \%$ and $32.8 \%)$ was recorded during 2016-2017 over 2015-2016 where 50\% N was applied as basal, and rest as guided by optical crop sensor over FFP (Table 5).

Table 3. Weed density $\S\left(\right.$ No. $\left.\mathrm{m}^{-2}\right)$ in maize as influenced by weed and nitrogen management in a maize-wheat system.

\begin{tabular}{|c|c|c|c|c|c|c|c|c|}
\hline \multirow{3}{*}{ Treatment } & \multicolumn{4}{|c|}{ 2015-2016 } & \multicolumn{4}{|c|}{ 2016-2017 } \\
\hline & \multicolumn{2}{|c|}{35 DAS } & \multicolumn{2}{|c|}{70 DAS } & \multicolumn{2}{|c|}{35 DAS } & \multicolumn{2}{|c|}{70 DAS } \\
\hline & BLW & NLW & BLW & NLW & BLW & NLW & BLW & NLW \\
\hline \multicolumn{9}{|c|}{ Weed management } \\
\hline UWC & $21.1^{\mathrm{a} *}$ & $28.6^{\mathrm{a}}$ & $40.3^{a}$ & $75.1^{\mathrm{a}}$ & $18.2^{\mathrm{a}}$ & $30.6^{a}$ & $34.2^{\mathrm{a}}$ & $78.6^{a}$ \\
\hline Atra + pendi (PRE) & $15.3^{b}$ & $20.5^{b}$ & $31.2^{\mathrm{a}}$ & $35.2^{\mathrm{a}}$ & $7.6^{b}$ & $8.1^{\mathrm{b}}$ & $18.2^{b}$ & $26.3^{b}$ \\
\hline $\mathrm{BM}+2,4-\mathrm{D}(\mathrm{POST})$ & $13.4^{\mathrm{b}}$ & $16.8^{\mathrm{b}}$ & $22.2^{b}$ & $32.4^{\mathrm{b}}$ & $4.3^{c}$ & $4.1^{\mathrm{c}}$ & $14.7^{\mathrm{c}}$ & $15.5^{\mathrm{c}}$ \\
\hline \multicolumn{9}{|c|}{ Nitrogen management } \\
\hline FFP & $22.3^{b}$ & $28.1^{b}$ & $40.1^{\mathrm{a}}$ & $62.5^{b}$ & $10.3^{\mathrm{ab}}$ & $16.10^{\mathrm{a}}$ & $22.7^{b}$ & $35.7^{b}$ \\
\hline 100\% Basal & $16.9^{a}$ & $24.5^{\mathrm{a}}$ & $32.9^{a}$ & $50.2^{\mathrm{a}}$ & $11.9^{\mathrm{a}}$ & $14.89 \mathrm{ab}$ & $31.3^{\mathrm{a}}$ & $49.3^{\mathrm{a}}$ \\
\hline $\begin{array}{l}75 \% \text { Basal + rest as } \\
\text { sensor guided }\end{array}$ & $17.4^{\mathrm{b}}$ & $20.1^{b}$ & $29.2^{b}$ & $44.2^{b}$ & $9.3^{a b}$ & $11.87^{a b}$ & $20.0^{b}$ & $31.5^{b}$ \\
\hline $\begin{array}{l}50 \% \text { Basal + rest as } \\
\text { sensor guided }\end{array}$ & $9.6^{c}$ & $15.1^{\mathrm{c}}$ & $22.3^{c}$ & $33.9^{\mathrm{c}}$ & $8.4^{b}$ & $9.67^{b}$ & $15.0^{\mathrm{c}}$ & $22.1^{\mathrm{c}}$ \\
\hline
\end{tabular}

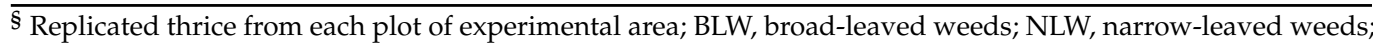
FFP: farmers fertilizers practice; UWC: unweeded check; PRE; pre-emergence herbicide application; POST: post-emergence herbicide application. * Means followed by different letters in each column for particular set of treatments are significantly different at $p \leq 0.05$ as per Tukey's HSD test. 
Table 4. Weed density $\S\left(\right.$ No. $\left.\mathrm{m}^{-2}\right)$ in wheat as influenced by weed and nitrogen management in a maize-wheat system.

\begin{tabular}{|c|c|c|c|c|c|c|c|c|}
\hline \multirow{3}{*}{ Treatment } & \multicolumn{4}{|c|}{ 2015-2016 } & \multicolumn{4}{|c|}{ 2016-2017 } \\
\hline & \multicolumn{2}{|c|}{35 DAS } & \multicolumn{2}{|c|}{70 DAS } & \multicolumn{2}{|c|}{35 DAS } & \multicolumn{2}{|c|}{70 DAS } \\
\hline & BLW & NLW & BLW & NLW & BLW & NLW & BLW & NLW \\
\hline \multicolumn{9}{|c|}{ Weed management } \\
\hline UWC & $11.1^{\mathrm{a} *}$ & $20.5^{\mathrm{a}}$ & $30.4^{\mathrm{a}}$ & $56.2^{\mathrm{a}}$ & $13.6^{\mathrm{a}}$ & $21.9^{a}$ & $43.5^{\mathrm{a}}$ & $90.3^{\mathrm{a}}$ \\
\hline $\begin{array}{c}\text { Pendi + carfentra } \\
\text { (PRE) }\end{array}$ & $10.8^{\mathrm{b}}$ & $15.1^{b}$ & $21.1^{\mathrm{b}}$ & $26.5^{b}$ & $3.6^{b}$ & $5.9^{b}$ & $12.9^{b}$ & $18.6^{\mathrm{b}}$ \\
\hline $\begin{array}{c}\text { Clodi + carfentra } \\
\text { (POST) }\end{array}$ & $6.4^{\mathrm{c}}$ & $9.0^{\mathrm{c}}$ & $17.2^{\mathrm{c}}$ & $21.1^{\mathrm{c}}$ & $2.1^{\mathrm{c}}$ & $4.3^{b}$ & $9.7^{b}$ & $15.5^{\mathrm{C}}$ \\
\hline \multicolumn{9}{|c|}{ Nitrogen management } \\
\hline FFP & $11.1^{\mathrm{a}}$ & $17.1^{b}$ & $24.6^{b}$ & $36.8^{b}$ & $6.9^{a b}$ & $11.2^{b}$ & $23.5^{b}$ & $43.2^{b}$ \\
\hline 100\% Basal & $10.4^{\mathrm{b}}$ & $19.1^{\mathrm{c}}$ & $31.0^{\mathrm{a}}$ & $45.3^{c}$ & $8.4^{\mathrm{a}}$ & $14.2^{\mathrm{a}}$ & $29.5^{\mathrm{a}}$ & $54.5^{\mathrm{a}}$ \\
\hline $\begin{array}{c}75 \% \text { Basal + rest as } \\
\text { sensor guided }\end{array}$ & $9.8^{b}$ & $14.1^{\mathrm{b}}$ & $20.8^{b}$ & $35.5^{\mathrm{b}}$ & $5.4^{\mathrm{b}}$ & $10.3^{b c}$ & $21.2^{b}$ & $38.7^{b}$ \\
\hline $\begin{array}{c}50 \% \text { Basal + rest as } \\
\text { sensor guided }\end{array}$ & $6.8^{c}$ & $9.6^{c}$ & $14.8^{\mathrm{c}}$ & $22.8^{\mathrm{c}}$ & $4.8^{b}$ & $7.08^{c}$ & $13.6^{c}$ & $28.9^{\mathrm{C}}$ \\
\hline
\end{tabular}

$\overline{\text { \$ Replicated thrice from each plot of experimental area; BLW, broad-leaved weeds; NLW, narrow-leaved weeds }}$ FFP: farmers fertilizers practice; UWC: unweeded check; PRE; pre-emergence herbicide application; POST: post-emergence herbicide application. * Means followed by different letters in each column for particular set of treatments are significantly different at $p \leq 0.05$ as per Tukey's HSD test.

Table 5. Weed dry biomass $\S\left(\mathrm{g} \mathrm{m}^{-2}\right)$ in maize and wheat as influenced by weed and nitrogen management.

\begin{tabular}{|c|c|c|c|c|c|c|c|c|}
\hline \multirow{3}{*}{ Treatment } & \multicolumn{4}{|c|}{ Maize } & \multicolumn{4}{|c|}{ Wheat } \\
\hline & \multicolumn{2}{|c|}{2015} & \multicolumn{2}{|c|}{2016} & \multicolumn{2}{|c|}{2015} & \multicolumn{2}{|c|}{2016} \\
\hline & $\begin{array}{c}35 \\
\text { DAS }\end{array}$ & $\begin{array}{c}70 \\
\text { DAS }\end{array}$ & $\begin{array}{c}35 \\
\text { DAS }\end{array}$ & $\begin{array}{c}70 \\
\text { DAS }\end{array}$ & $\begin{array}{c}35 \\
\text { DAS }\end{array}$ & $\begin{array}{c}70 \\
\text { DAS }\end{array}$ & $\begin{array}{c}35 \\
\text { DAS }\end{array}$ & $\begin{array}{c}70 \\
\text { DAS }\end{array}$ \\
\hline \multicolumn{9}{|c|}{ Weed management } \\
\hline UWC & $40.7^{\mathrm{a}}$ & $101.2^{\mathrm{a}}$ & $47.5^{\mathrm{a}}$ & $148.6^{a}$ & $31.5^{\mathrm{a}}$ & $92.5^{\mathrm{a}}$ & $41.2^{\mathrm{c}}$ & $121.8^{\mathrm{a}}$ \\
\hline Atra + pendi (PRE) & $19.5^{\mathrm{b}}$ & $64.5^{\mathrm{b}}$ & $17.5^{\mathrm{b}}$ & $75.6^{\mathrm{b}}$ & $22.2^{\mathrm{b}}$ & $65.8^{\mathrm{b}}$ & $15.5^{\mathrm{b}}$ & $43.5^{b}$ \\
\hline $\mathrm{BM}+2,4-\mathrm{D}(\mathrm{POST})$ & $17.6^{\mathrm{c}}$ & $57.3^{\mathrm{b}}$ & $15.3^{b}$ & $43.7^{b}$ & $15.3^{\mathrm{a}}$ & $35.5^{\mathrm{c}}$ & $8.4^{b}$ & $25.6^{c}$ \\
\hline \multicolumn{9}{|c|}{ Nitrogen management } \\
\hline FFP & $28.2^{\mathrm{b}}$ & $74.7^{\mathrm{b}}$ & $24.6^{\mathrm{b}}$ & $88.6^{\mathrm{b}}$ & $32.5^{b}$ & $75.2^{b}$ & $23.1^{\mathrm{b}}$ & $66.7^{\mathrm{b}}$ \\
\hline $100 \%$ Basal & $34.1^{\mathrm{a}}$ & $94.6^{\mathrm{a}}$ & $31.2^{\mathrm{a}}$ & $118.6^{\mathrm{a}}$ & $34.5^{\mathrm{c}}$ & $96.8^{\mathrm{a}}$ & $28.2^{\mathrm{a}}$ & $84.1^{\mathrm{a}}$ \\
\hline $\begin{array}{c}75 \% \text { Basal + rest as } \\
\text { sensor guided }\end{array}$ & $25.5^{\mathrm{b}}$ & $68.5^{\mathrm{b}}$ & $21.5^{\mathrm{b}}$ & $78.9^{b}$ & $26.6^{\mathrm{b}}$ & $69.5^{b}$ & $20.2^{b c}$ & $59.9^{b}$ \\
\hline $\begin{array}{c}50 \% \text { Basal + rest as } \\
\text { sensor guided }\end{array}$ & $19.4^{\mathrm{c}}$ & $50.2^{\mathrm{c}}$ & $17.7^{\mathrm{c}}$ & $67.2^{\mathrm{c}}$ & $18.2^{\mathrm{a}}$ & $51.2^{\mathrm{c}}$ & $16.3^{c}$ & $42.5^{c}$ \\
\hline
\end{tabular}

$\overline{\text { \$ Replicated thrice from each plot of experimental area; BLW, broad-leaved weeds; NLW, narrow-leaved weeds }}$ FFP: farmers fertilizers practice; UWC: unweeded check; PRE; pre-emergence herbicide application; POST: postemergence herbicide application. $\mathrm{a}, \mathrm{b}, \mathrm{c}, \mathrm{d}$ Means followed by different letters in each column for particular set of treatments are significantly different at $p \leq 0.05$ as per Tukey's HSD test.

\subsection{Weed Interference in Wheat}

A total of ten BLW and four NLW species were identified in the field during the winter season. The predominant BLW weeds were Chenopodium murale L., Melilotus alba Medik., Chenopodium album L. and Anagallis arvensis L. and the predominant NLW species were Avena fatua L., Phalaris minor Retz. and Cynodon dactylon (L.) Pers. The weed density of NLW species was more than BLW species invariably under all treatments. The minimum weed 
density was recorded where clodinafop-propargyl plus carfentrazone (POST) was applied. During 2015-2016, after the POST application at 25 DAS, a 3.4- and 3.5-fold reduction in the BLW and NLW density were recorded at 35 DAS, respectively (Table 4). A 2.1- and 2.6-fold higher weed dry biomass was recorded under weedy check over the application of clodinafop-propargyl plus carfentrazone (POST) at 25 DAS during 2015-2016 (Table 4). During 2016-2017, a 4.9- and 4.8-fold reduction in the weed density in wheat were recorded in the treated plots over the weedy check. The weed density at both stages increased where $100 \%$ N was applied as basal over FFP. The density of both NLW and BLW remained similar in FFP and N3 where $75 \% \mathrm{~N}$ was applied as basal, and rest as guided by optical sensor. A significant reduction of $39.8 \%$ and $38.1 \%$ was recorded in the weed dry biomass of BLW and NLW at 70 DAS, respectively, where $50 \% \mathrm{~N}$ was applied as basal, and rest as guided by optical sensor over FFP during 2015-2016 (Table 5).

\subsection{Weed Community Composition and NLW: BLW Ratio in Maize and Wheat}

We found a distinct effect of tillage and system design for weed management on the weed community composition (Figure 2). The relative dominance of NLW over BLW was recorded across all weed and $\mathrm{N}$ treatments invariably in both crops. The ratio of NLW: BLW increased in UWC from 35 to 70 DAS in both maize and wheat substantiating that in the absence of any weed management method, perennial NLW remain abundant and the NLW:BLW ratio increases under ZT. The NLW:BLW ratio reduced significantly from 35 to 70 DAS in maize, where either atrazine plus pendimethalin (PRE) was applied or maizeSesbania co-culture was done. Likewise, in wheat, the NLW:BLW ratio reduced, where either carfentrazone plus pendimethalin (PRE) or clodinafop-propargyl plus carfentrazone (POST) was applied.
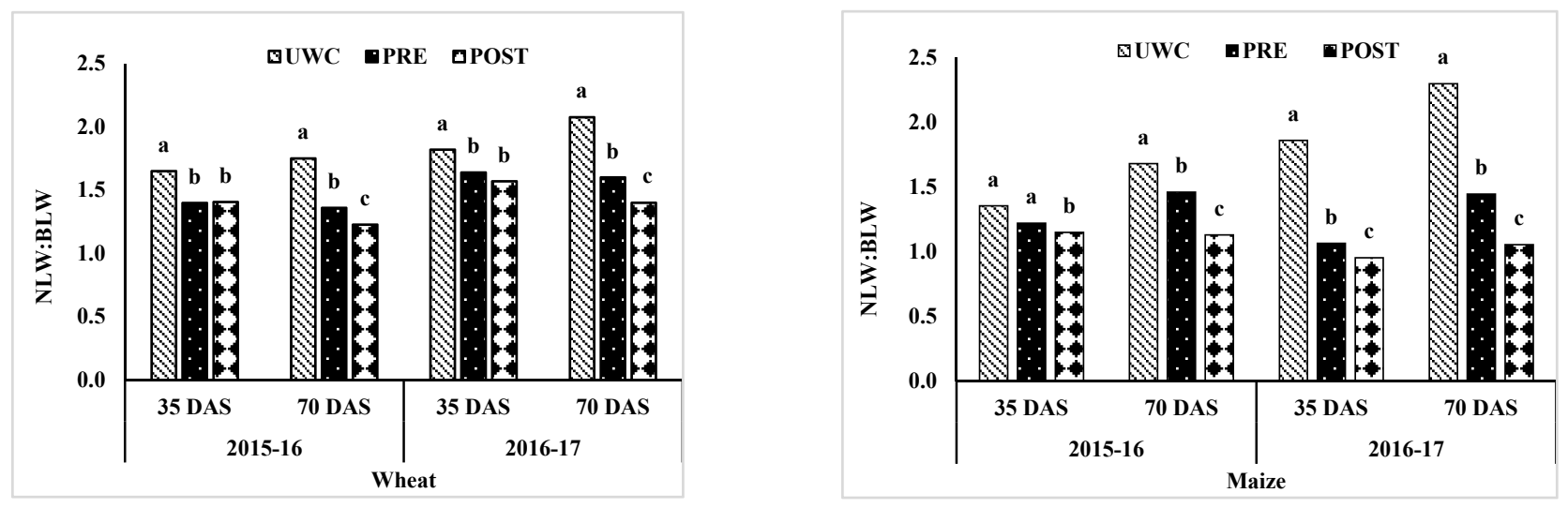

Figure 2. Narrow leaf (NLW) and broad leaf weed (BLW) density ratio in maize and wheat during 2015-2016 and 2016-2017.

\subsection{Physiological Parameters and Agronomic Productivity of Maize and Wheat}

The weed management factor included three independent variables, while nitrogen management factor included four independent variables, while the dependable variables include dry matter accumulation, leaf area index and grain yield for both maize and wheat. The $p$ value of ANOVA revealed that these physiological and agronomic parameters of maize and wheat were significantly influenced by weed and $\mathrm{N}$ management interaction (Tables 6 and 7). The ANOVA was worked out for the analysis of main effect of weed $(\mathrm{W})$ and nitrogen $(\mathrm{N})$ management and their interactive effect $(\mathrm{W} \times \mathrm{N})$ on growth and productivity of maize and wheat (Tables 6 and 7). The F probabilities revealed that weed and nitrogen management significantly influenced the dry matter, leaf area index and productivity of both maize and wheat. However, the effect of nitrogen management options was found highly significant and the interaction for growth parameters remained non-significant. The W X N interactive effect was found significant on maize yield during 
2015-2016 and 2016-2017 ( $p=0.004$ and $p=0.007$, respectively) and wheat productivity $(p=0.0045)$ during the second year only (Tables 6 and 7$)$.

Table 6. Analysis of variance (ANOVA) of dry matter production (DM), leaf area index (LAI) and grain yield of maize, showing the effects of nitrogen management $(\mathrm{N})$, weed management $(\mathrm{W})$ and their interactions.

\begin{tabular}{|c|c|c|c|c|c|c|c|}
\hline \multirow{3}{*}{ Sources of Variation } & \multirow{3}{*}{ DF } & \multicolumn{6}{|c|}{$p$ Value } \\
\hline & & \multicolumn{2}{|c|}{ DM } & \multicolumn{2}{|c|}{ LAI } & \multicolumn{2}{|c|}{ Grain Yield (t/ha) } \\
\hline & & 2015-2016 & 2016-2017 & 2015-2016 & 2016-2017 & 2015-2016 & 2016-2017 \\
\hline Replication & 2 & - & - & - & - & - & - \\
\hline Weed management (W) & 2 & $0.01865 *$ & 0.0108 * & $0.01865 *$ & 0.0108 * & $0.0006^{* *}$ & $0.0003^{* *}$ \\
\hline Error (a) & 4 & - & - & - & - & - & - \\
\hline Nitrogen management $(\mathrm{N})$ & 3 & $0.0000^{* *}$ & $0.000^{* *}$ & $0.0000 * *$ & $0.000^{* *}$ & $0.0001^{* *}$ & $0.001^{* *}$ \\
\hline $\mathrm{N} \times \mathrm{W}$ & 6 & $\begin{array}{c}0.8932 \\
(\mathrm{~ns})\end{array}$ & $\begin{array}{c}0.704 \\
\text { (ns) }\end{array}$ & 0.8932 (ns) & $\begin{array}{c}0.704 \\
\text { (ns) }\end{array}$ & $0.00441^{* *}$ & $0.0070^{* *}$ \\
\hline Error (b) & 18 & - & - & - & - & - & - \\
\hline
\end{tabular}

* Significant at $p \leq 0.05 ;{ }^{* *}$ significant at $p \leq 0.01 ; \mathrm{ns}$, non-significant at $p \leq 0.05$.

Table 7. Analysis of variance (ANOVA) of dry matter production (DM), leaf area index (LAI) and grain yield of wheat, showing the effects of nitrogen management $(\mathrm{N})$, weed management $(\mathrm{W})$ and their interactions.

\begin{tabular}{|c|c|c|c|c|c|c|c|}
\hline \multirow{3}{*}{ Sources of Variation } & \multirow{3}{*}{ DF } & \multicolumn{6}{|c|}{$p$ Value } \\
\hline & & \multicolumn{2}{|c|}{ DM } & \multicolumn{2}{|c|}{ LAI } & \multicolumn{2}{|c|}{ Grain Yield (t/ha) } \\
\hline & & $2015-2016$ & 2016-2017 & 2015-2016 & $2016-2017$ & 2015-2016 & 2016-2017 \\
\hline Replication & 2 & - & - & - & - & - & - \\
\hline Weed management (W) & 2 & 0.0170 * & $0.0035^{* *}$ & $0.0033^{* *}$ & $0.0005^{* *}$ & $0.0003^{* *}$ & 0.0296 * \\
\hline Error (a) & 4 & - & - & - & - & - & - \\
\hline Nitrogen management $(\mathrm{N})$ & 3 & $0.0000 * *$ & $0.0000 * *$ & $0.0000 * *$ & $0.0000 * *$ & $0.0001^{* *}$ & $0.0001^{* *}$ \\
\hline $\mathrm{N} \times \mathrm{W}$ & 6 & 0.5291 (ns) & 0.9831 (ns) & $0.5728(\mathrm{~ns})$ & 0.9123 (ns) & 0.1125 (ns) & $0.0045^{* *}$ \\
\hline Error (b) & 18 & - & - & - & - & - & - \\
\hline
\end{tabular}

* Significant at $p \leq 0.05 ; *$ significant at $p \leq 0.01 ; \mathrm{ns}$, non-significant at $p \leq 0.05$.

In maize, significantly higher dry matter accumulation and leaf area index at 70 DAS was recorded where maize-Sesbania co-culture was done over atrazine plus pendimethalin (PRE) during the second year (Table 8). The dry matter of wheat under pendimethalin plus carfentrazone (PRE) and clodinafop-propargyl plus carfentrazone (POST) were significantly superior over UWC. Among N management treatments, the highest dry matter and leaf area index in both maize and wheat were recorded where $50 \% \mathrm{~N}$ was applied as basal and rest as sensor-guided and the minimum were recorded where the entire $\mathrm{N}$ was applied as basal. 
Table 8. Dry matter $\left(\mathrm{kg} \mathrm{m}^{-2}\right)$ and leaf area index (LAI) at $70 \mathrm{DAS}$ and grain yield $\left(\mathrm{t} \mathrm{ha}^{-1}\right)$ of maize as influenced by nitrogen and weed management.

\begin{tabular}{|c|c|c|c|c|c|c|}
\hline \multirow{2}{*}{ Treatment } & \multicolumn{2}{|c|}{ DM } & \multicolumn{2}{|c|}{ LAI } & \multicolumn{2}{|c|}{ Grain Yield } \\
\hline & 2015-2016 & 2016-2017 & 2015-2016 & 2016-2017 & 2015-2016 & 2016-2017 \\
\hline \multicolumn{7}{|l|}{ Weed Management } \\
\hline UWC & $0.52^{b}$ & $0.52^{\mathrm{c}}$ & $4.46^{\mathrm{b}}$ & $4.65^{c}$ & $4.37^{\mathrm{c}}$ & $4.22^{c}$ \\
\hline Atra + pendi (PRE) & $0.56^{\mathrm{a}}$ & $0.56^{\mathrm{b}}$ & $4.95^{\mathrm{a}}$ & $5.17^{\mathrm{b}}$ & $5.33^{b}$ & $5.47^{\mathrm{b}}$ \\
\hline $\mathrm{BM}+2,4-\mathrm{D}(\mathrm{POST})$ & $0.59^{\mathrm{a}}$ & $0.63^{\mathrm{a}}$ & $5.28^{a}$ & $5.46^{\mathrm{a}}$ & $5.92^{\mathrm{a}}$ & $6.08^{a}$ \\
\hline \multicolumn{7}{|l|}{ Nitrogen management } \\
\hline FFP & $0.52^{c}$ & $0.54^{\mathrm{c}}$ & $4.52^{c}$ & $4.71^{\mathrm{c}}$ & $5.14^{\mathrm{b}}$ & $5.17^{b}$ \\
\hline $100 \%$ Basal & $0.46^{\mathrm{d}}$ & $0.46^{\mathrm{d}}$ & $4.04^{\mathrm{d}}$ & $4.22^{\mathrm{d}}$ & $4.88^{\mathrm{c}}$ & $4.83^{\mathrm{c}}$ \\
\hline $75 \%$ Basal + rest as sensor guided & $0.60^{b}$ & $0.60^{b}$ & $5.11^{b}$ & $5.29^{b}$ & $5.23^{b}$ & $5.35^{b}$ \\
\hline $50 \%$ Basal + rest as sensor guided & $0.64^{\mathrm{a}}$ & $0.67^{\mathrm{a}}$ & $5.94^{\mathrm{a}}$ & $6.15^{\mathrm{a}}$ & $5.57^{\mathrm{a}}$ & $5.69^{a}$ \\
\hline
\end{tabular}

BLW, broad-leaved weeds; NLW, narrow-leaved weeds; FFP: farmers fertilizers practice; UWC: unweeded check; PRE; pre-emergence herbicide application; POST: post-emergence herbicide application. ${ }^{a, b, c, d}$ Means followed by different letters in each column for particular set of treatments are significantly different at $p \leq 0.05$ as per Tukey's HSD test.

During both years, the highest maize (5.92 and $6.08 \mathrm{t} / \mathrm{ha}$ ) and wheat yields (4.91 and $5.40 \mathrm{t} / \mathrm{ha}$ ) were recorded under brown manure and clodinafop-propargyl plus carfentrazone (POST), respectively (Table 9). A $35.5 \%$ and $44.2 \%$ increase in maize seed yield was recorded with maize-Sesbania co-culture over UWC, respectively, in 2015-2016 and 20162017. During 2015-2016, the at par wheat seed yield was recorded under pendimethalin plus carfentrazone (PRE) and clodinafop-propargyl plus carfentrazone (POST), however during the second year, the highest wheat seed yield was recorded with clodinafoppropargyl plus carfentrazone (POST), followed by pendimethalin plus carfentrazone (PRE). A $27.2 \%$ and $23.3 \%$ higher wheat seed yield was recorded with clodinafop-propargyl plus carfentrazone (POST) application over UWC during the two years (Table 9).

Table 9. Leaf area index (LAI), dry matter $\left(\mathrm{kg} \mathrm{m}^{-2}\right)$ at 70 DAS and grain yield of wheat as influenced by nitrogen and weed management.

\begin{tabular}{|c|c|c|c|c|c|c|}
\hline \multirow{2}{*}{ Treatment } & \multirow{2}{*}{$\begin{array}{c}\text { DM } \\
2015-2016\end{array}$} & \multirow[b]{2}{*}{ 2016-2016 } & \multicolumn{2}{|l|}{ LAI } & \multicolumn{2}{|l|}{ Grain Yield } \\
\hline & & & 2015-2016 & 2016-2016 & 2015-2016 & 2016-2016 \\
\hline \multicolumn{7}{|l|}{ Weed Management } \\
\hline UWC & $0.23^{\mathrm{b}}$ & $0.25^{b}$ & $4.18^{\mathrm{c}}$ & $4.98^{b}$ & $3.86^{\mathrm{b}}$ & $4.38^{c}$ \\
\hline Pendi + carfentra (PRE) & $0.27^{\mathrm{a}}$ & $0.29^{\mathrm{a}}$ & $4.39^{\mathrm{b}}$ & $5.34^{\mathrm{b}}$ & $4.76^{\mathrm{a}}$ & $5.16^{\mathrm{b}}$ \\
\hline Clodi + carfentra (POST) & $0.29^{\mathrm{a}}$ & $0.31^{\mathrm{a}}$ & $5.22^{\mathrm{a}}$ & $5.78^{\mathrm{a}}$ & $4.91^{\mathrm{a}}$ & $5.40^{\mathrm{a}}$ \\
\hline \multicolumn{7}{|l|}{ Nitrogen management } \\
\hline FFP & $0.24^{\mathrm{c}}$ & $0.26^{\mathrm{c}}$ & $4.18^{\mathrm{c}}$ & $5.03^{c}$ & $4.33^{b}$ & $4.82^{c}$ \\
\hline $100 \%$ Basal & $0.20^{\mathrm{c}}$ & $0.22^{c}$ & $3.69^{c}$ & $4.46^{\mathrm{d}}$ & $4.13^{b}$ & $4.54^{\mathrm{d}}$ \\
\hline $75 \%$ Basal + rest as sensor guided & $0.28^{b}$ & $0.30^{b}$ & $4.94^{\mathrm{b}}$ & $5.68^{\mathrm{b}}$ & $4.67^{\mathrm{a}}$ & $5.14^{\mathrm{b}}$ \\
\hline $50 \%$ Basal + rest as sensor guided & $0.32^{\mathrm{a}}$ & $0.34^{\mathrm{a}}$ & $5.58^{\mathrm{a}}$ & $6.29^{a}$ & $4.91^{\mathrm{a}}$ & $5.43^{\mathrm{a}}$ \\
\hline
\end{tabular}

BLW, broad-leaved weeds; NLW, narrow-leaved weeds; FFP: farmers fertilizers practice; UWC: unweeded check; PRE; pre-emergence herbicide application; POST: post-emergence herbicide application. a,b,c,d Means followed by different letters in each column for particular set of treatments are significantly different at $p \leq 0.05$ as per Tukey's HSD test.

With nutrient management options, the highest maize and wheat grain yield was recorded where $50 \% \mathrm{~N}$ was applied as basal and rest as sensor-guided, followed by where $75 \% \mathrm{~N}$ was applied as basal and rest as sensor-guided (Table 8). The grain yield under 50\% $\mathrm{N}$ application as basal and rest as guided by sensor and FFP remained comparable, and 
the minimum was recorded where the entire $\mathrm{N}$ was applied as basal. An $8.4 \%$ and $10.1 \%$ increase in the maize seed yield was recorded with $50 \% \mathrm{~N}$ application as basal and rest as guided by sensor over FFP (Table 9). Likewise, wheat seed yield under FFP and 100\% $\mathrm{N}$ application as basal remained similar during the first year. During the second year, a $13.4 \%$ increase in the wheat seed yield was recorded where $50 \% \mathrm{~N}$ application as basal and rest as guided by the sensor over FFP. In maize, a highly significant interaction between $\mathrm{N}$ and weed management was recorded during both 2015-2016 and 2016-2017 ( $p$-value; 0.00441 and 0.0070 during 2015-2016 and 2016-2017, respectively, Table 10). However, in succeeding wheat, it remained significant only during 2016-2017 ( $p$-value; 0.0045 , Table 11).

Table 10. Grain yield of maize $\left(\mathrm{t} \mathrm{ha}^{-1}\right)$ due to interaction between nitrogen and weed management.

\begin{tabular}{|c|c|c|c|c|c|c|c|c|}
\hline \multirow{3}{*}{$\begin{array}{c}\text { Treatment } \\
\text { Weed } \\
\text { Management }\end{array}$} & \multicolumn{8}{|c|}{ Nitrogen Management } \\
\hline & \multicolumn{4}{|c|}{ 2015-2016 } & \multicolumn{4}{|c|}{ 2016-2016 } \\
\hline & FFP & $\begin{array}{l}100 \% \\
\text { Basal }\end{array}$ & $\begin{array}{l}75 \% \text { Basal + } \\
\text { Rest as Sensor } \\
\text { Guided }\end{array}$ & $\begin{array}{c}50 \% \text { Basal + } \\
\text { Rest as Sensor } \\
\text { Guided }\end{array}$ & FFP & $\begin{array}{l}100 \% \\
\text { Basal }\end{array}$ & $\begin{array}{l}75 \% \text { Basal }+ \\
\text { Rest as Sensor } \\
\text { Guided }\end{array}$ & $\begin{array}{c}50 \% \text { Basal + } \\
\text { Rest as Sensor } \\
\text { Guided }\end{array}$ \\
\hline UWC & $\begin{array}{l}4.40 \\
\mathrm{C} * \mathrm{~b} * *\end{array}$ & $4.18^{\mathrm{Bb}}$ & $4.40^{\mathrm{Cb}}$ & $4.50^{\mathrm{Ca}}$ & $\begin{array}{l}4.25 \\
\mathrm{Bb}\end{array}$ & $3.90^{\mathrm{Bb}}$ & $4.36^{\mathrm{Cb}}$ & $4.38^{\mathrm{Ca}}$ \\
\hline $\begin{array}{l}\text { Atra + pendi } \\
\text { (PRE) }\end{array}$ & $\begin{array}{l}5.27 \\
\mathrm{Bb}\end{array}$ & $5.07^{\mathrm{Ab}}$ & $5.30^{\mathrm{Bb}}$ & $5.70^{\mathrm{Ba}}$ & $\begin{array}{l}5.42 \\
\mathrm{Ab}\end{array}$ & $5.16^{\mathrm{Ab}}$ & $5.50^{\mathrm{Ba}}$ & $5.81^{\mathrm{Ba}}$ \\
\hline $\begin{array}{l}\mathrm{BM}+2,4-\mathrm{D} \\
(\mathrm{POST})\end{array}$ & $\begin{array}{l}5.77 \\
\mathrm{Ab}\end{array}$ & $5.40^{\mathrm{Ac}}$ & $6.00 \mathrm{Ab}$ & $6.50^{\mathrm{Aa}}$ & $\begin{array}{c}5.83 \\
\mathrm{Aa}\end{array}$ & $5.43^{\mathrm{Ab}}$ & $6.18^{\mathrm{Aa}}$ & $6.87^{\mathrm{Aa}}$ \\
\hline
\end{tabular}

UWC: unweeded check; PRE; pre-emergence herbicide application; POST: post-emergence herbicide application. * Values followed by different capital case letter within a column are significant at $p \leq 0.05 .{ }^{* *}$ Values followed by different small letter within a row are significant at $p \leq 0.05$.

Table 11. Grain yield of wheat $\left(\mathrm{t} \mathrm{ha}^{-1}\right)$ due to interaction between nitrogen and weed management.

\begin{tabular}{|c|c|c|c|c|c|c|c|c|}
\hline \multirow{2}{*}{ Treatment } & \multicolumn{8}{|c|}{ Nitrogen Management } \\
\hline & \multicolumn{4}{|c|}{ 2015-2016 } & \multicolumn{4}{|c|}{ 2016-2016 } \\
\hline $\begin{array}{c}\text { Weed } \\
\text { Management }\end{array}$ & FFP & $\begin{array}{l}100 \% \\
\text { Basal }\end{array}$ & $\begin{array}{c}75 \% \text { Basal + } \\
\text { Rest as Sensor } \\
\text { Guided }\end{array}$ & $\begin{array}{c}50 \% \text { Basal + } \\
\text { Rest as Sensor } \\
\text { Guided }\end{array}$ & FFP & $\begin{array}{l}100 \% \\
\text { Basal }\end{array}$ & $\begin{array}{c}75 \% \text { Basal + } \\
\text { Rest as Sensor } \\
\text { Guided }\end{array}$ & $\begin{array}{c}50 \% \text { Basal + } \\
\text { Rest as Sensor } \\
\text { Guided }\end{array}$ \\
\hline UWC & $3.72 \mathrm{Bb} *$ & $3.47^{\mathrm{Bb}}$ & $4.05^{\mathrm{Aa}}$ & 4.19 Аа & $4.19^{\mathrm{Bb} * *}$ & $4.05^{\mathrm{Ab}}$ & $4.52^{\mathrm{Bb}}$ & $4.77^{\mathrm{Bb}}$ \\
\hline $\begin{array}{c}\text { Pendi + carfentra } \\
\text { (PRE) }\end{array}$ & $4.64^{\mathrm{Bb}}$ & $4.54^{\mathrm{Bc}}$ & $4.79^{\mathrm{Bb}}$ & $5.07^{\mathrm{Aa}}$ & $5.03^{\mathrm{Bb}}$ & $4.80^{\mathrm{Bb}}$ & $5.29^{\mathrm{Bb}}$ & $5.52 \mathrm{Aa}$ \\
\hline $\begin{array}{l}\text { Clodi + carfentra } \\
(\text { POST })\end{array}$ & $4.62^{\mathrm{BC}}$ & $4.40^{\mathrm{Bd}}$ & $5.18^{\mathrm{Ab}}$ & $5.47^{\mathrm{Aa}}$ & $5.23^{\mathrm{Bb}}$ & $4.78^{\mathrm{Bb}}$ & $5.60^{\mathrm{Aa}}$ & $6.00 \mathrm{Aa}$ \\
\hline
\end{tabular}

UWC: unweeded check; PRE; pre-emergence herbicide application; POST: post-emergence herbicide application. * Values followed by different capital case letter within a column are significant at $p \leq 0.05$. ${ }^{* *}$ Values followed by different small letter within a row are significant at $p \leq 0.05$.

\subsection{Fitted Linear Regression Analysis between Agronomic Productivity and Weed Interference}

After two growing seasons, the linear regression studies on maize and wheat productivity with weed density and weed dry biomass at 35 and 70 DAS were carried out. The regression coefficient between crop yield and weed dry biomass was statistically significant between crop yield and weed density (significant at $p \leq 0.05$ at 35 DAS and $p \leq 0.01$ at 70 DAS) (Figures 3 and 4). The negative relationship of maize and wheat seed yield (dependent variable, $\mathrm{Y}$ ) with weed density (independent variable, $\mathrm{X}$ ) and weed biomass (independent variable, $X$ ) after the two years of experiment at 35 and 75 DAS have been given in the Figures 3 and 4 . The regression equation for maize yield and weed density was $\mathrm{Y}=-0.047 \mathrm{X}+7.01$ and $\mathrm{Y}=-0.061 \mathrm{X}+8.44$ at 35 and $75 \mathrm{DAS}$, respectively. These equations for maize seed yield and weed biomass were $Y=0.058 X+6.62$ and $Y=-0.04 X+7.83$ at 35 and 70 DAS, respectively. The regression equations for wheat seed yield and weed 
density were $Y=-0.0247 X+5.55$ and $Y=-0.0305 X+6.29$ at 35 and 70 DAS, respectively. However, these equations for wheat seed yield and weed biomass at 35 and 70 DAS were $Y=-0.035 X+5.07$ and $Y=-0.0152 X+5.22$, respectively. This linear regression model also signifies that a $61.9 \%$ and $70.1 \%$ variation in maize and $59.5 \%$ and $62.8 \%$, in wheat yield were observed due to the weed density and weed biomass, respectively at 70 DAS. The adjusted R Squared values have been given as a better model evaluator which can correlate the variables more efficiently.
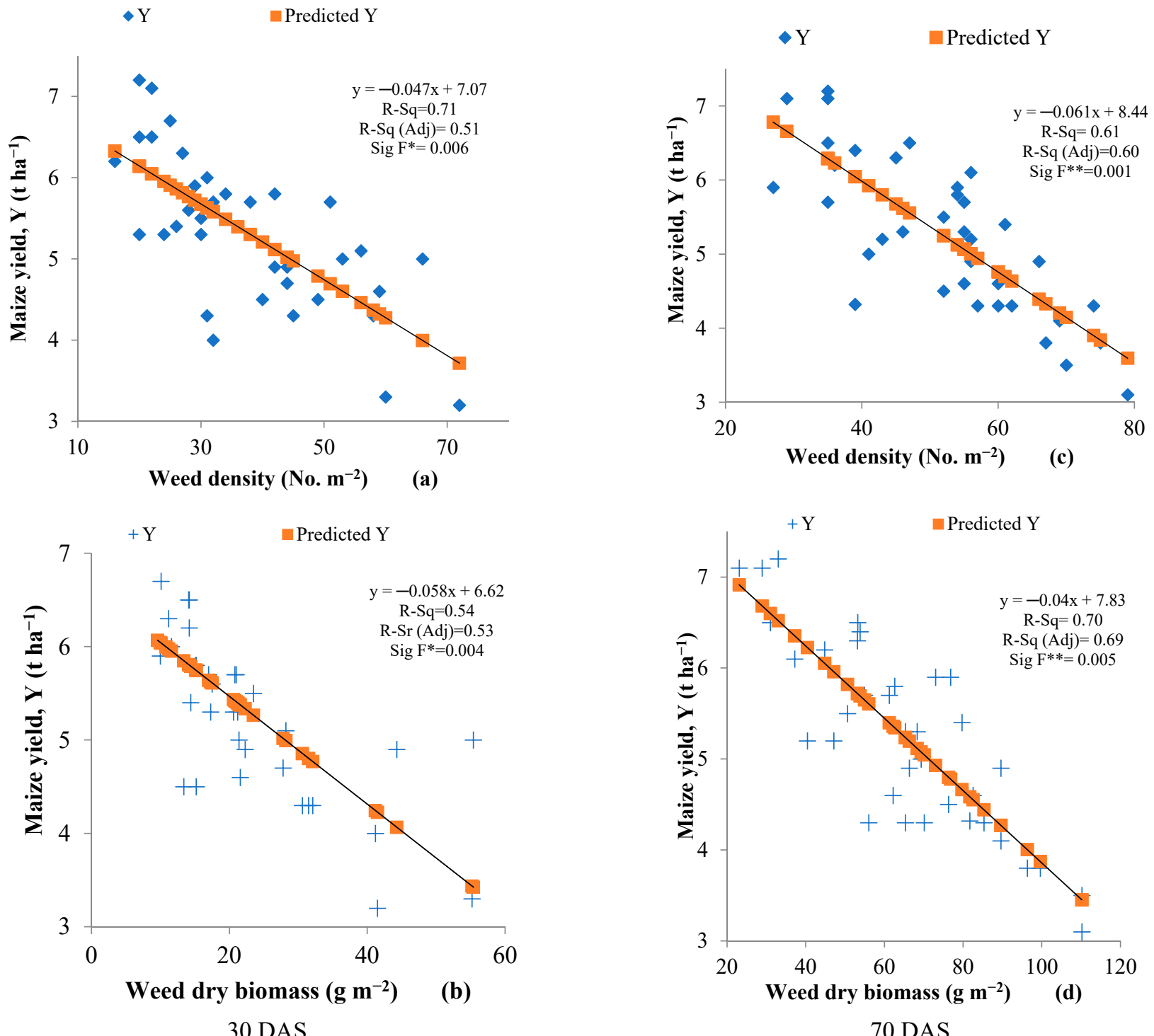

30 DAS

70 DAS

Figure 3. Linear regression predicting weed density and dry biomass as a function of maize yield at 35 DAS (a,b) and 70 DAS (c,d) against weed and nitrogen management options (after 2 years of experimentation). 
$\Delta \mathrm{Y} \quad \square \quad$ Predicted $\mathrm{Y}$
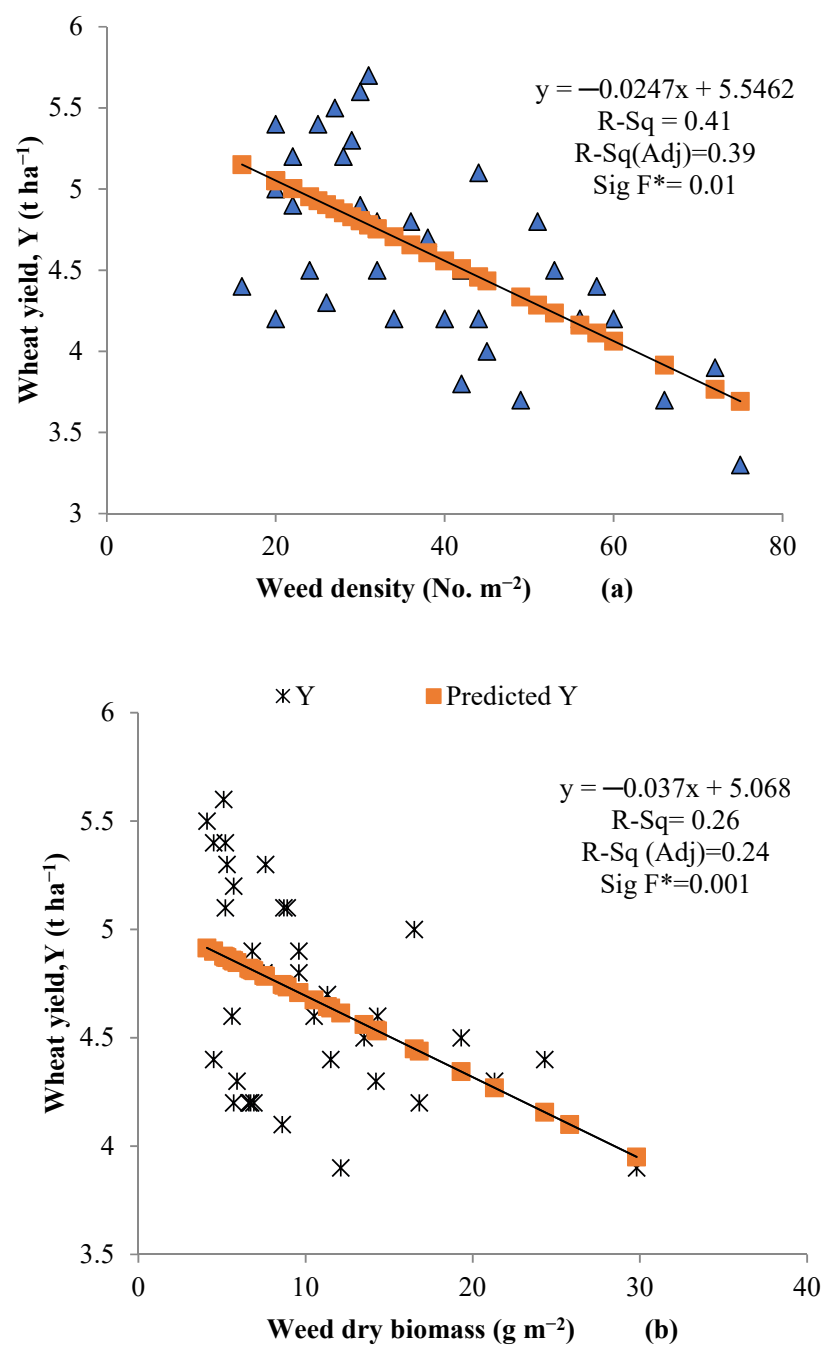

30 DAS
$\Delta \mathrm{Y} \quad-$ Predicted $\mathrm{Y}$
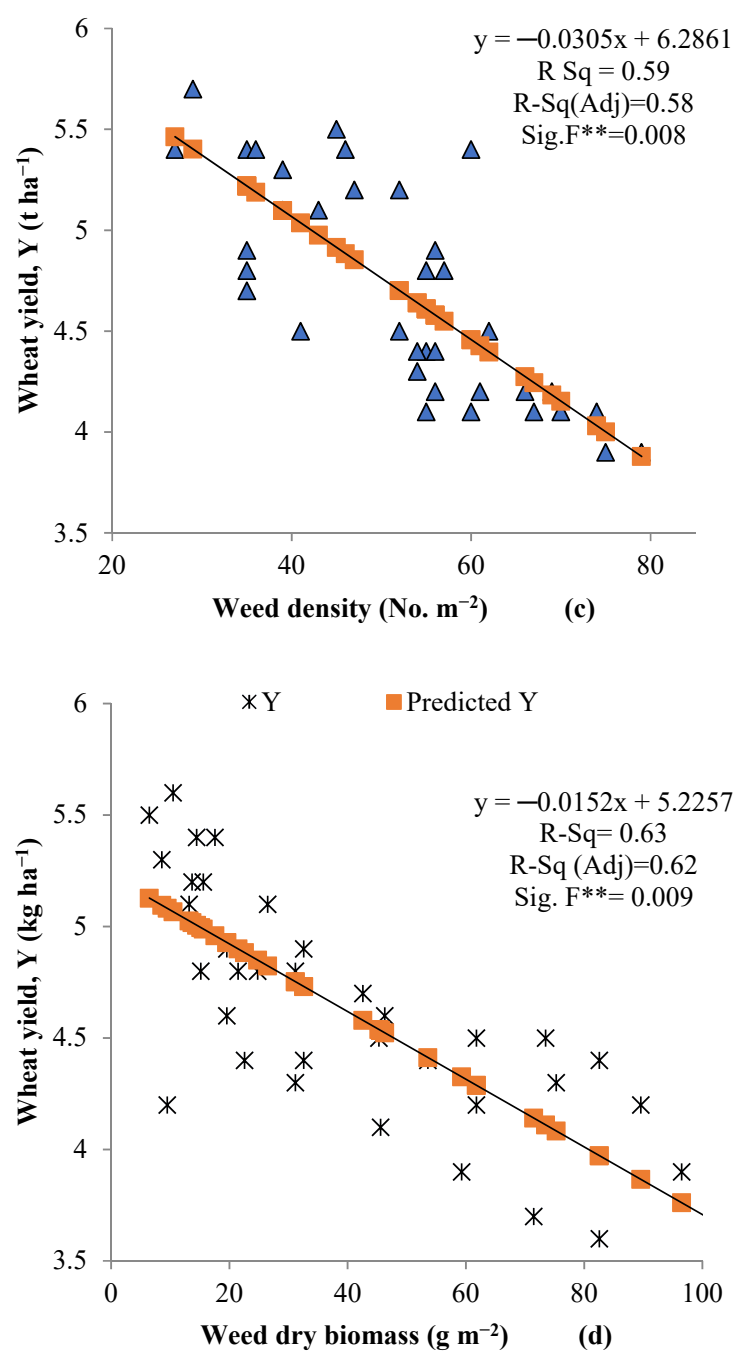

70 DAS

Figure 4. Linear regression predicting weed density and dry biomass as a function of wheat yield at 35 (a,b) and 70 DAS $(\mathbf{c}, \mathbf{d})$, against weed and nitrogen management options (after 2 years of experimentation).

\section{Discussion}

\subsection{Optical Crop Sensor Based N Use and Global Warming Potential}

The sensor-based $\mathrm{N}$ application resulted in a saving of 25 and $56 \mathrm{~kg} \mathrm{~N} /$ ha doses where $50 \%$ and $75 \% \mathrm{~N}$ was applied as basal, and rest as guided by optical crop sensor during the first year. Similarly, N doses reduced to 23 and $59 \mathrm{~kg} \mathrm{~N} /$ ha during 2016-2016. The lower emissions with $50 \%$ basal $\mathrm{N}$ and rest as sensor guided compared to FPP was attributed to efficient $\mathrm{N}$ use and net saving of fertilizer [22]. The poor $\mathrm{N}$ use efficiency in high $\mathrm{N}$ fertilizer requiring cereal crops like maize and wheat may result up to $40 \%$ losses of applied $\mathrm{N}$ from subtropical and tropical world [23]. Since, $25 \%$ of the total green-house gas emission is from agriculture sector alone, the $\mathrm{N}$ saving results in reduction of $\mathrm{N}_{2} \mathrm{O}$ gas emission also [24]. Thus, a real time $\mathrm{N}$ management strategy offering higher $\mathrm{N}$ use efficiency and net $\mathrm{N}$ saving reduces the threat of global warming. Moreover, precision $\mathrm{N}$ management by using optical crop sensor matches with the crop $\mathrm{N}$ demand both spatially and temporally, thus increases $\mathrm{N}$ use efficiency and mitigate negative environmental impacts [25]. 


\subsection{Weed Interference in Maize and Wheat}

The simultaneous reduction in weed population and yield enhancement with Sesbania co-culture has been widely reported in rice and maize [26,27]. A reduction of up to $76-83 \%$, $20-33 \%$ and $37-80 \%$ in the BLW, NLW density and total weed density, respectively, has been reported in rice [28]. The significant reduction in the BLW density through brown manure over UWC at 35 and 70 DAS suggests that maize-Sesbania co-culture complements weed management and promotes soil nutrient build up (Table 3). The reduction in BLW density remains higher over NLW in the present study but maize-Sesbania co-culture as a live mulch offers concurrent and residual effects on perennial weeds; especially Cyperus rotundus, reduces herbicide use, thereby reducing the likelihood of development of herbicide resistance $[29,30]$. Maize-Sesbania co-culture resulted in better weed management by providing a longer weed free period over atrazine plus pendimethalin (PRE). The application of pre-emergence herbicide alone as a weed management strategy remains less effective, especially during rainy season where repeated weed emergence occur with every flush of rain. Moreover, the spatial pattern of maize and Sesbania growing together rapidly exploit applied and indigenous soil $\mathrm{N}$ which offer competition for weeds [31,32].

Weed dry weight is a more reliable measure over weed density to evaluate the cropweed interaction, its impact on yield and efficacy of herbicides [33,34]. The less turn-over period between rainy and winter seasons and slow rate of residue decomposition due to low ambient temperatures under ZT provides a distinct mulching effect in succeeding wheat crop. This initial resistance to weed emergence and the subsequent application of clodinafop-propargyl plus carfentrazone (POST) was found effective to prevent weeds in wheat (Table 4). Thus, Sesbania brown manure in rainy season and application of POST herbicides alone in wheat resulted in minimum weed infestation under the maize-wheat system studied. Weed communities under maize-Sesbania co-culture were potentially less competitive due to less height even if the total weed abundance may be higher [35].

However, weed pressure increases exponentially under UWC even under CA due to weed seed bank build-up over years. $\mathrm{N}$ application strongly influenced the crop-weed interference by breaking weed-seed dormancy, stimulating weed emergence increasing weed densities and weed biomass. A quick mineralization of initial higher $\mathrm{N}$ application may result in an $\mathrm{N}$ shortage at later stages of the crop and thus, weeds which can survive even at low $\mathrm{N}$ requirements are favored under ZT [36]. Hence, the synergy in brown manure and sensor-guided $\mathrm{N}$ application helps in soil health restoration by improving nutrient cycling stimulate crop growth to compete with weeds at critical growth stages and accrue the weed management benefits by reducing and delaying weed emergence [34]. N supplied as per the crop requirement as sensor-guided also offered a competitive advantage to both maize and wheat crops over weeds [7,37].

\subsection{Weed Community Composition and NLW: BLW Ratio in Maize and Wheat}

Understanding about the conceivable weed shift and ecological succession due to adoption of any weed management approach under CA remains desirable. The community composition, dominance and distribution of weeds is unquestionably governed by the type and timing of herbicide application which may favor or undermine any particular weed [37]. The study reported a wider NLW:BLW ratio where no weed management practice was followed (Figure 2). The dominance of perennial NLW and sedges over BLW across all weed and $N$ treatments in both crops was recorded due to the ecological preference of NLW under ZT [38] and their ability to germinate from the soil surface [39-41]. The relatively higher NLW:BLW ratio in maize with atrazine plus pendimethalin (PRE) over Sesbania brown manure indicates that the PRE herbicide application alone is inadequate to manage predominant rainy seasons NLW, viz. Cynodon dactylon and Cyperus rotundus. These weeds with creeping roots/rhizomes are further favored under ZT [42]. Similarly, in wheat, the higher NLW:BLW ratio under the clodinafop-propargyl plus carfentrazone (POST) necessitates the need for alternate herbicides to reduce dominant NLW weeds like Avena fatua and Phalaris minor. Under ZT, the weed seedling emergence is not restricted 
due to deep burial and also the NLW have higher seed number due to small size [43]. The small seeds of most of the NLW tend to have higher persistence in the soil over large seeds. Adoption of certain multi-purpose resource conservation technology like residue retention and brown manure with judicious chemical weed management might also potentially alter this weed shift towards NLW [44].

\subsection{Physiological Parameters and Agronomic Productivity of Maize and Wheat}

Both dry matter and leaf area index are important physiological traits contributing to weed competitiveness in cereals [45] and they correlate well with NDVI at the peak flowering stage of crop development [46]. Greater radiation interception and shading ability with higher leaf area index reduce weed growth and improve crop dry matter accumulation. The trend and response pattern of dry matter and leaf area index resulted in higher maize and wheat productivity under sensor-guided $\mathrm{N}$ application over FFP (Tables 7 and 8). In maize, the respective yield loss due to weed infestation was $18.1 \%$ and $26.2 \%$ over atrazine + pendimethalin (PRE) and maize-Sesbania co-culture (2, 4-D POST) during 2015-2016. This reduction was $22.9 \%$ and 30.6\%, respectively, during 2016-2017. The rapid initial growth of Sesbania even before majority of weeds emerge fundamentally improves weed's competitive ability of crops, increases soil organic matter content by $13.0 \%$ and results in higher yield (9). Sesbania brown manure accumulates around 3.1 and $1.21 \mathrm{t} \mathrm{ha}^{-1}$ fresh and dry biomass, respectively, during initial 25 days. It accumulates $35.7 \mathrm{~kg} \mathrm{~N}, 3.9 \mathrm{~kg}$ phosphorus and $17.2 \mathrm{~kg}$ potassium per hectare, respectively, in 30 DAS. An increase in the nutrient availability through brown manure improves both crop growth and seed yield [47,48].

The optimum $\mathrm{N}$ management as per crop needs enhances crop competitiveness against weeds [49]. The significant interaction between weed and $\mathrm{N}$ management showed that the highest yield was obtained under maize-Sesbania co-culture and $50 \% \mathrm{~N}$ application as basal and rest as sensor-guided (Table 6). Hence, use of sensor-based precision $\mathrm{N}$ management tools also reduces the environmental cost paid by the farmers in terms of less fertilizer use over the conventional practices. The synergy between growing Sesbania and sensorguided $\mathrm{N}$ application prevent $\mathrm{N}$ losses through volatilization and oxidation. Adequate moisture due to frequent rains during the rainy season stimulates large numbers of weed seeds, which when killed by 2,4-D POST application in Sesbania serves to deplete the seed bank which is the main source of new infestation and abundance of annual weeds [50]. Subsequently, maize residues in wheat also prevent the early emergence of weeds. Under a long-term residue retained ZT field, the POST herbicide application in wheat remains essential. Herbicide application greatly improved grain yield and exploring a double ZT system (i.e., ZT maize-ZT wheat) with residue retention in both crops and application of herbicide mixtures offers more benefits from a single application [17], besides reduced fertilizer use, increased yield and profitability in wheat under CA in the Indo-Gangetic Plains [13]. The regression coefficient was found highly significant (significant at $p \leq 0.01$ ) between seed yield of maize and wheat with weed density and weed dry biomass at 70 DAS over 35 DAS (significant at $p \leq 0.05$ ), respectively, indicates that any weed management option adopted at the later stage which coincides with the grand growth phases of crops has been found more beneficial (Figures 3 and 4).

\subsection{Agronomic Productivity and Weed Interference}

The estimation of dependency was performed using a simple linear regression model. The trend line drawn across the variants revealed that the weed dry biomass and grain yield variation predicted a stronger negative regression coefficient (Figures 3 and 4). Many important weeds are equally, rather more responsive to higher $\mathrm{N}$ fertilization than crops at the initial stages, especially when no herbicides are used. Thus, $\mathrm{N}$ fertilization significantly increased weed density and dry matter [51-53]. The regression analysis also indicates that weed dry biomass is a more decisive indicator of crop-weed interference. The higher 
regression coefficient (significant at $p \leq 0.01$ ) at 70 DAS necessitates the application of POST weed management option in both maize and wheat.

\section{Conclusions}

The 10 billion expected global population by 2050 highpoints that the maize and wheat yields must increase by $18 \%$ and $15 \%$, respectively. Hence, the challenges of poor $\mathrm{N}$ management and weed competition in maize-wheat system must be urgently addressed. The present study suggests that Sesbania brown manure as a low-external input in maize, collectively with sequential low-dose and high efficacy herbicides in wheat under a maizewheat system can potentially reduce the weed peril under CA. A $36 \%$ and $44 \%$ increase in maize seed yield and a $27 \%$ and $23 \%$ increase in wheat seed yield with the interaction of Sesbania brown manure in maize and clodinafop-propargyl + carfentrazone (POST) in wheat over unweeded check, respectively, clearly suggests that post-emergence herbicide treatment remains essential to manage weeds in rainy season maize and in wheat till 60 DAS. However, either pre-emergence herbicide application or brown manure alone cannot offer a complete solution. Selection of a broad-spectrum pre-emergence herbicide, viz. pendimethalin followed by brown manure could be more efficient. Higher crop productivity and enhanced use efficiency of $\mathrm{N}$ fertilizers with sensor-guided $\mathrm{N}$ application complements weed management and addresses emerging issues of increasing costs and declining profit margins. Sensor-based $\mathrm{N}$ application also resulted in a significant reduction of GHG emissions from these two important staple food crops in the subtropical world. The novel information generated through the present study can however be fine-scaled and refined for in-field adjustment per se the need and the resource base of the growers for achieving robust yields under variable environments. The complimentary approaches for weed and nutrient management proposed in the study could recommend broad domains to balance trade-offs in CA between minimum soil disturbance for higher crop yields and adequate weed management. However, the regionally explicit predictions of the damage potential by weeds from this study demand further studies on understanding the ecological basis of the weed shifts from BLW to NLW. The crop-weed relation and the function attributes of weed communities can be further validated based on the suitability of their eco-physiological profiles largely under CA-based systems.

Author Contributions: K.S.: Conceptualization, Investigation and Writing-Original draft; V.K.S.: Conceptualization, Founding Acquisition and Resources; S.S.R.: Conceptualization, Investigation and Software; R.R.: Formal Analysis, Investigation and Methodology; T.K.D.: Methodology, Visualization and writing-review \& editing. All authors have read and agreed to the published version of the manuscript.

Funding: The research work is funded by Division of Agronomy, ICAR-Indian Agricultural Research Institute, Pusa, New Delhi.

Institutional Review Board Statement: Not applicable.

Informed Consent Statement: Not applicable.

Acknowledgments: The authors are highly thankful to the Head, Division of Agronomy and the Director, ICAR-IARI, Pusa, New Delhi.

Conflicts of Interest: No potential conflict of interest was reported by the author.

\section{References}

1. Anonymous. Conservation Agriculture I The International Maize and Wheat Improvement Center (CIMMYT). 2021. Available online: https: / / www.cimmyt.org/Cimmyt.org (accessed on 12 January 2021).

2. Parihar, C.M.; Jat, S.L.; Singh, A.K.; Kumar, B.; Pradhan, S.; Pooniya, V.; Dahuja, A.; Chaudhary, V.; Jat, M.L.; Jat, R.K.; et al. Conservation agriculture in irrigated intensive maize-based systems of north-western India: Effects on crop yields, water productivity and economic profitability. Field Crops Res. 2016, 193, 104-116. [CrossRef]

3. Singh, M.; Sidhu, H.S.; Humphreys, E.; Thind, H.S.; Jat, M.L.; Blackwell, J.; Singh, V. Nitrogen management for zero till wheat with surface retention of rice residues in north-west India. Field Crops Res. 2015, 184, 183-191. [CrossRef] 
4. $\quad$ Das, T.K.; Saharawat, Y.S.; Bhattacharyya, R.; Sudhishri, S.; Bandyopadhyay, K.K.; Sharma, A.R.; Jat, M.L. Conservation agriculture effects on crop and water productivity, profitability and soil organic carbon accumulation under a maize-wheat cropping system in the North-western Indo-Gangetic plains. Field Crops Res. 2018, 215, 222-231. [CrossRef]

5. Gharde, Y.; Singh, P.K.; Dubey, R.P.; Gupta, P.K. Assessment of yield and economic losses in agriculture due to weeds in India. Crop Prot. 2018, 107, 12-18. [CrossRef]

6. Susha, V.S.; Das, T.K.; Nath, C.P.; Pandey, R.; Paul, S.; Ghosh, S. Impacts of tillage and herbicide mixture on weed interference, agronomic productivity and profitability of a maize-wheat system in the Northwestern IGPs. Field Crops Res. 2018, 219, 180-191. [CrossRef]

7. Ali, A.M.; Abou-Amer, I.; Ibrahim, S.M. Using Optical crop sensor active optical sensor for optimizing maize nitrogen fertilization in calcareous soils of Egypt. Arch. Agron. Soil Sci. 2018, 64, 1083-1093.

8. Ramesh, K.; Matloob, A.; Aslam, F.; Florentine, S.K.; Chauhan, B.S. Weeds in a Changing Climate: Vulnerabilities, Consequences, and Implications for Future Weed Management. Front. Plant Sci. 2017, 8, 95. [CrossRef] [PubMed]

9. Sarangi, D.R.; Sahoo, T.R.; Sethy, S.; Chourasia, M.; Prasad, S.M.; Mohanta, R.K. Effect of replacing a part of nitrogenous fertilizer by brown manuring in direct seeded rice: A field study. Oryza 2016, 53, 226-228.

10. Tanwar, S.P.S.; Singh, A.K.; Joshi, N. Changing environment and sustained crop production: A challenge for agronomy. J. Arid. Legumes 2010, 7, 91-100.

11. Maitra, S.; Zaman, A. Brown Manuring, an Effective Technique for Yield Sustainability and Weed Management of Cereal Crops: A Review. Int. J. Bioresour. Sci. 2017, 4, 1-5. [CrossRef]

12. Maity, S.K.; Mukherjee, P.K. Effect of brown manuring on grain yield and nutrient use efficiency in dry direct seeded kharif rice. Indian J. Weed Sci. 2011, 43, 61-66.

13. Sapkota, T.B.; Majumdar, K.; Jat, M.L.; Kumara, A.; Bishnoi, D.K.; Mcdonald, A.J.; Pampolino, M. Precision nutrient management in conservation agriculture-based wheat production of Northwest India: Profitability, nutrient use efficiency and environmental footprint. Field Crops Res. 2014, 155, 233-244. [CrossRef]

14. Chauhan, B.S.; Abugho, S.B. Weed management in mechanized-sown, zero-till dry-seeded rice. Weed Technol. 2013, $27,28-33$. [CrossRef]

15. Blackshaw, R.E.; Brandt, R.N.; Janzen, H.H.; Entz, T.; Grant, C.A.; Derksen, D.A. Differential response of weed species to added nitrogen. Weed Sci. 2003, 51, 532-539. [CrossRef]

16. Nath, C.P.; Das, T.K.; Rana, K.S.; Pathak, H.; Bhattacharyya, R.; Sangeeta, P.; Singh, S.B.; Meena, M.C. Weed-management and wheat productivity in a conservation agriculture-based maize (Zea mays)-wheat (Triticum aestivum)-mungbean (Vigna radiata) system in north-western Indo-Gangetic plains of India. Indian J. Agron. 2015, 60, 554-563.

17. Oyeogbe, A.I.; Das, T.K.; Bhatia, A.; Singh, S.B. Adaptive nitrogen and integrated weed management in conservation agriculture: Impacts on agronomic productivity, greenhouse gas emissions, and herbicide residues. Environ. Monit. Assess. 2017, $189,198$. [CrossRef]

18. Bijay-Singh, S.R.; Kaur, J.; Jat, M.L.; Yadvinder-Singh, S.V.; Chandna, P.; Choudhary, O.P.; Gupta, R.K.; Thind, H.S. In-season estimation of yield and nitrogen management in irrigated wheat using a hand-held optical sensor in the Indo-Gangetic plains of South Asia. Agron. Sustain. Dev. 2011, 31, 589-603. [CrossRef]

19. Raun, W.R.; Solie, J.B.; Johnson, G.V.; Stone, L.; Mullen, R.W.; Freeman, K.W.; Thomason, W.E.; Lukina, E.V. Improving nitrogen use efficiency in cereal grain production with optical sensing and variable rate application. Agron. J. 2002, 94, 815-820. [CrossRef]

20. Bijarniya, D.; Parihar, C.M.; Jat, R.K.; Kalvania, K.; Kakraliya, S.K.; Jat, M.L. Portfolios of Climate Smart Agriculture Practices in Smallholder Rice-Wheat System of Eastern Indo-Gangetic Plains-Crop Productivity, Resource Use Efficiency and Environmental Foot Prints. Agronomy 2020, 10, 1561. [CrossRef]

21. Snedecor, G.W.; Cochran, W.G. Statistical Methods, 8th ed.; Iowa State University Press: Ames Iowa, IA, USA, 1989.

22. Raun, W.R.; Solie, J.B.; Stone, M.L.; Martin, K.L.; Freeman, K.W.; Mullen, R.W.; Zhang, H.; Schepers, J.S.; Johnson, G.V. Optical sensor-based algorithm for crop nitrogen fertilization. Commun. Soil Sci. Plant Anal. 2005, 36, 2759-2781. [CrossRef]

23. Reay, D.S.; Davidson, E.A.; Smith, A. Global agriculture and nitrous oxide emissions. Nat. Clim. Chang. 2012, 6, 410-416. [CrossRef]

24. Walsh, O.S.; Shafian, S.; Christiaens, R.J. Evaluation of sensor-based nitrogen rates and sources in wheat. Hindawi Int. J. Agron. 2018. [CrossRef]

25. Fabbri, C.; Napoli, M.; Verdi, L.; Mancini, M.; Orlandini, S.; Marta, A.D. A Sustainability Assessment of the Optical crop sensor N Management Tool: A Lysimetric Experiment on Barley. Sustainability 2020, 12, 7303. [CrossRef]

26. Singh, V.P.; Singh, S.P.; Kumar, A.; Banga, A.; Tripathi, N. Effect of monsoon \& weed mgt on growth and yield of direct seeded rice. Indian J. Weed Sci. 2012, 44, 147-150.

27. Bommayasamy, N.; Singh, L.B.; Pandey, V.K.; Nanda, B.K.; Nayak, H.; Kundu, A. Efficacy of rice cum dhaincha (Sesbania aculeata) intercropping on weed control, growth, yield and economics of rice. J. Pharmacogn. Phytochem. 2019, 8, 3257-3260.

28. Singh, S.; Singh, G. Evaluation of different methods of establishment in wheat (Triticum aestivum) after different methods of rice establishment. Pantnagar. J. Res. 2007, 5, 36-40.

29. Gupta, R.K.; Seth, A. A review of resource conserving technologies for sustainable management of the rice-wheat cropping system of IGPs. Crop Prot. 2007, 26, 436-447. [CrossRef] 
30. Singh, S.; Ladha, J.K.; Gupta, R.K.; Bhushan, L.; Rao, A.N.; Sivaprasad, B.; Singh, P.P. Evaluation of mulching, intercropping with Sesbania and herbicide use for weed management in dry-seeded rice. Crop Prot. 2007, 26, 518-524. [CrossRef]

31. Medd, R.W.; Auld, B.A.; Kemp, D.R.; Murison, R.D. The influence of wheat density and spatial arrangement on annual ryegrass competition. Aust. J. Agric. Res. 1985, 36, 361-371. [CrossRef]

32. Das, T.K.; Bhattacharyya, R.; Sharma, A.R.; Das, S.; Saad, A.A.; Pathak, H. Impacts of conservation agriculture on total soil organic carbon retention potential under irrigated agro-ecosystem of the western Indo-Gangetic Plains. Eur. J. Agron. 2013, 51, 34-42.

33. Das, T.K.; Yaduraju, N.T. Optimization of metribuzin use for controlling isoproturon-resistant Phalaris minor Retz. in wheat. Pestic. Res. J. 2002, 14, 47-56.

34. Joshi, E.; Kumar, D.; Lal, B.; Nepalia, V.; Gautam, P.; Vyas, A.K. Management of direct seeded rice for enhanced resource-use efficiency. Plant Knowl. J. 2013, 2, 119-134.

35. Armengot, L.; Berner, A.; Blanco-Moreno, J.M.; Mäder, P.; Sans, F.X. Long-term feasibility of reduced tillage in organic farming. Agron. Sustain. Dev. 2015, 35. [CrossRef]

36. Ali, A.M. Using Hand-Held Chlorophyll Meters and Canopy Reflectance Sensors for Fertilizer Nitrogen Management in Cereals in Small Farms in Developing Countries. Sensors 2020, 20, 11-27.

37. Tuesca, D.; Puricelli, E.; Papa, J. A long-term study of weed flora shifts indifferent tillage systems. Weed Res. 2001, 41, 369-382. [CrossRef]

38. Nandan, R.; Singh, V.; Singh, S.S.; Virender Kumar Hazra, K.K.; Nath, C.P.; Poonia, S.P.; Malik, R.K. Comparative assessment of the relative proportion of weed morphology, diversity, and growth under new generation tillage and crop establishment techniques in rice-based cropping systems. Crop Prot. 2018, 111, 23-32. [CrossRef]

39. Taa, A.; Tanner, D.; Bennie, A.T. Effects of stubble management, tillage and cropping sequence on wheat production in the south-eastern highlands of Ethiopia. Soil Till. Res. 2004, 76, 69-82. [CrossRef]

40. Mishra, J.S.; Singh, V.P. Effect of tillage and weed control on weed- dynamics, crop productivity, and energy-use efficiency in rice (Oryza sativa L.)-based cropping systems in Vertisols. Indian J. Agric. Sci. 2011, 81, 129-133.

41. Nath, C.P.; Das, T.K.; Ranam, K.S.; Bhattacharyya, R.; Pathak, H.; Paul, S.; Meena, M.C.; Singh, S.B. Weed and nitrogen management effects on weed infestation and crop productivity of wheat-mung bean sequence in conventional and conservation tillage practices. Agric. Res. 2017, 6, 33-46. [CrossRef]

42. Shekhawat, K.; Rathore, S.S.; Kandpal, B.K.; Premi, O.P.; Singh, D.; Chauhan, B.S. Crop establishment techniques affect productivity, sustainability and soil health under mustard-based cropping systems of Indian semi-arid regions. Soil Till. Res. 2016, 158, 137-146. [CrossRef]

43. Kapila, S.; Rathore, S.S.; Bhagirath, S. Chauhan Review Weed Management in Dry Direct-Seeded Rice: A Review on Challenges and Opportunities for Sustainable Rice Production. Agronomy 2020, 10, 1264. [CrossRef]

44. Gill, G.; Bhullar, M.S.; Yadav, A.; Yadav, D.B. Technology for successful production of direct seeded rice. In A Training Manual Based on the Outputs of ACIAR Funded Project CSE/2004/033; CCSHAU: Hisar, Haryana, 2013; p. 32.

45. Mahajan, G.; Ramesh, M.S.; Chauhan, B.S. Genotypic Differences for Water-Use Efficiency and Weed Competitiveness in Dry Direct-Seeded Rice. Agron. J. 2015, 107, 1573-1584. [CrossRef]

46. Eitel, J.U.H. Combined spectral index to improve ground-based estimates of nitrogen in dryland wheat. Agron. J. 2008, 100, 1694-1702. [CrossRef]

47. Walsh, O.S.; Klatt, A.R.; Solie, J.B.; Godsey, C.B.; Raun, W.R. Use of soil moisture data for refined Optical crop sensor sensor based nitrogen recommendations in winter wheat (Triticum aestivum L.). Precis. Agric. 2013, 14, 343-356. [CrossRef]

48. Kamboj, B.R.; Kumar, A.; Bishnoi, D.K.; Singla, K.; Kumar, V.; Jat, M.L.; Chaudhary, N.; Jat, H.S.; Gosain, D.K.; Khippal, A. Direct Seeded Rice Technology in Western Indo-Gangetic Plains of India: CSISA Experiences; CSISA, IRRI and CIMMYT: New Delhi, India, 2012; p. 16.

49. Singh, S.; Chhokar, R.S.; Gopal, R.; Virender, K.; Singh, M. Integrated weed management -A key for success of direct seeded rice. In Proceedings of the 4th World Congress on Conservation Agriculture, New Delhi, India, 4-7 February 2009 ; p. 182.

50. Mahajan, G.; Timsina, J. Effect of nitrogen rates and weed control methods on weeds abundance and yield of direct-seeded rice. Arch. Agron. Soil Sci. 2011, 57, 239-250. [CrossRef]

51. Angiras, N.; Chopra, P.; Kumar, S. Weed seed bank and dynamics of weed flora as influenced by tillage and weed control methods in maize. Agric. Sci. Dig. 2010, 30, 6-10.

52. Mahajan, G.; Chauhan, B.S. Herbicide options for weed control in dry-seeded aromatic rice in India. Weed Technol. 2013, 27, 682-689. [CrossRef]

53. Jiang, M.; Liu, T.; Huang, N.; Shen, X.; Shen, M.; Dai, Q. Effect of long-term fertilisation on the weed community of a winter wheat field. Sci. Rep. 2018, 8, 4017. [CrossRef] [PubMed] 